\title{
Local inundation distances and regional tsunami recurrence in the Indian Ocean inferred from luminescence dating of sandy deposits in Thailand
}

\author{
D. Brill ${ }^{1}$, N. Klasen ${ }^{1}$, K. Jankaew ${ }^{2}$, H. Brückner ${ }^{1}$, D. Kelletat ${ }^{1}$, A. Scheffers ${ }^{3}$, and S. Scheffers ${ }^{4}$ \\ ${ }^{1}$ Institute of Geography, Universität zu Köln, Albertus-Magnus-Platz, 50923 Köln, Germany \\ ${ }^{2}$ Department of Geology, Faculty of Science, Chulalongkorn University, Bangkok, 10330, Thailand \\ ${ }^{3}$ Southern Cross GeoScience, Southern Cross University, Military Rd, Lismore, NSW 2480, Australia \\ ${ }^{4}$ MarineEcology Research Centre, Southern Cross University, Military Rd, Lismore, NSW 2480, Australia \\ Correspondence to: D. Brill (brilld@ uni-koeln.de)
}

Received: 30 September 2011 - Revised: 19 January 2012 - Accepted: 28 February 2012 - Published: 12 July 2012

\begin{abstract}
The Holocene beach-ridge plain of Phra Thong Island (Ko Phra Thong, SW Thailand) provides sedimentary evidence of several palaeotsunamis, in addition to the deposit of the 2004 Indian Ocean tsunami. Due to poor preservation conditions, these palaeoevent layers are restricted to swales. Correlation across beach ridges, which is important e.g. to reconstruct inundation distances, remains a major challenge. A primary tool for establishing a precisely confined correlation of the sand sheets is the use of chronological data. Since the application of radiocarbon dating is limited by the scarcity of appropriate material, this study utilised optically stimulated luminescence (OSL) dating of tsunamigenic quartz grains. Generally, the sediments showed favourable luminescence properties regarding signal intensity, dose recovery and thermal stability. Disturbances of the OSL signal due to partial bleaching were corrected using the minimum age model. At least three palaeoevents - being 490-550, 925-1035 and 1740-2000 yr old - were distinguished by dating the discontinuous sand sheets at four different sites. Besides this chronological framework, the OSL data provide the opportunity to correlate the discontinuous sand sheets between spatially separated sites within the same swale as well as across ridges. This allows for first estimates of inundation distances for the palaeotsunamis documented on Phra Thong Island. Furthermore, the two younger events overlap in age with contemporaneous tsunami and earthquake evidence from other coasts bordering the Indian Ocean.
\end{abstract}

\section{Introduction}

Geological evidence has been used successfully to identify prehistoric tsunami events and to reconstruct their recurrence probability in many risk areas of the world for more than twenty years (e.g. Atwater, 1987; Dawson et al., 1988; Nanayama et al., 2003; Pinegina et al., 2003; Cisternas et al., 2005; Dawson and Stewart, 2007; Engel et al., 2010; papers in Mastronuzzi et al., 2010). This is particularly important in regions that lack written sources, like many countries around the Indian Ocean, where historical records, if available, are restricted to the last 400 or so years (Murty and Rafiq, 1991; Kumar and Achyuthan, 2006; Dominey-Howes et al., 2007). In contrast, changes in the coastal geomorphology by erosion, deposition, uplift and subsidence, caused by the Indian Ocean Tsunami (IOT) and its triggering earthquake, demonstrate that tsunami impact may leave its signature in the geological record (e.g. Szczucinski et al., 2006; Choowong et al., 2007; Kelletat et al., 2007; Kayanne et al., 2007; Sibuet et al., 2007; Srinivasalu et al., 2007; Fagherazzi and Du, 2008; Morton et al., 2008; Paris et al., 2009; Switzer et al., 2012). While co-seismic movement at near-field sites along the rupture area is used to detect palaeoearthquakes that might have generated past tsunamis (e.g. Rajendran et al., 2008; Sieh et al., 2008), the research on coasts distant from the seismic zones, such as SW Thailand, concentrates on sedimentary evidence of tsunami impacts (e.g. Monecke et al., 2008; Dahanayake and Kulasena, 2008; Jankaew et al., 2008, Brill et al., 2011). However, due to the lack of archives along the west coast of Thailand, an accurate chronology remains to be defined. The most promising results so far originate from 
Phra Thong Island (Ko Phra Thong), where up to four sand sheets, inferred to be tsunamigenic, and older than 2004, are preserved in the swales of a wide beach-ridge plain (Jankaew et al., 2008).

Although crucial for establishing recurrence rates of prehistoric tsunami events, the dating of tsunamigenic sand sheets on Phra Thong remains a major challenge (Jankaew et al., 2011). The importance of well-constrained chronological data is further stressed by the fact that dating of tsunamites seems to be the only possibility to correlate layers between different sites on the island, especially across ridges. This information is necessary, e.g. to reconstruct inundation distances that may function as a valuable indicator for the magnitude of the events. Due to intensive tropical weathering, bioturbation, root penetration and anthropogenic impacts, the preservation potential on Phra Thong is low, and the disturbed and discontinuous sand sheets persisted only in the lowest parts of the undulating topography. In addition, the use of radiocarbon dating is restricted by the scarcity of datable macro-remains in the peaty soils confining the tsunami deposits, and by the uncertainty of ages obtained from plant fragments inside the sand sheets, since it is often reworked material of an older age (Jankaew et al., 2008; Fujino et al., 2009). Thus, optically stimulated luminescence (OSL) dating may provide a useful tool to establish a reliable chronological framework for the tsunami history of the island.

In general, OSL dating has the advantage to measure the time elapsed since sedimentation and, therefore, provides direct information about the time of deposition, while sandwich dating with the radiocarbon technique results in limiting ages. Various studies conducted in the last few years demonstrate that luminescence dating is principally suited to determine burial ages of tsunamigenic sandy sediments (e.g. Huntley and Clague, 1996; Banerjee et al., 2001; Murari et al., 2007; Cunha et al., 2010), although it is associated with several uncertainties; especially partial bleaching of the luminescence signal due to short and highly turbulent transport conditions in tsunami waves (Bishop et al., 2005; Murari et al., 2007) or inhomogeneous dose rates may be a problem locally. Nonetheless, OSL dating of IOT deposits and palaeotsunami sediments of known age, conducted in two recent studies, proved the general applicability of the method for tsunamigenic sand sheets on Phra Thong (Brill et al., 2012; Prendergast et al., 2012). The presented work aims to use OSL ages of tsunamigenic quartz grains to (1) improve the chronology of tsunami events on Phra Thong, and (2) enable the correlation of distinct layers, preserved in different swales of the island. To achieve this, discontinuous sand sheets inferred to be tsunamigenic were dated at several sites of the same swale. Based on these ages, a correlation of layers within the swale and, by considering existing chronological data of previous studies, across ridges was conducted.

\section{Physical setting}

The island of Phra Thong is located off the Andaman Sea coast of Southern Thailand, 125 kilometres north of Phuket (Fig. 1a), where it forms part of a system of barrier islands (Sinsakul, 1992). Separated from the mainland by tidal channels less than $4 \mathrm{~km}$ wide and $10 \mathrm{~m}$ deep, it extends up to $15 \mathrm{~km}$ from north to south and $8 \mathrm{~km}$ in an east-west direction. The topography of the island is dominated by several sequences of shore parallel swales and beach ridges (Fig. 1b), which reach heights of 2-5 $\mathrm{m}$ above mean sea level (a.s.l.). While these structures are predominantly covered by mangroves and dense vegetation in the eastern part of Phra Thong, grassy ridges and wet, tree-lined swales build up a $3 \mathrm{~km}$ wide, open beach-ridge plain with favourable properties for the accumulation of tsunami deposits in the west of the island.

Although SW Thailand is part of the tectonically stable Malay-Thai Peninsula with negligible seismic activity during the Holocene (Tjia, 1996), the active subduction zone of the Sunda Arc is located directly west of the study area. Due to the convergence of the Indo-Australian Plate and the Sunda and Burma Microplates, the area is a major source of tsunami-generating earthquakes, which are capable of producing waves strong enough to reach the Thai coast, as observed in December 2004 (Lay et al., 2005; Subarya et al., 2006). Although no historical tsunami prior to 2004 has been reported to have affected SW Thailand significantly (Bilham et al., 2005; Fig. 1a), convergence rates at the Sunda Arc (Løvholt et al., 2006) and evidence of co-seismic uplift (Rajendran et al., 2008; Meltzner et al., 2010) point to previous megathrust ruptures similar in magnitude to 2004, which probably resulted in severe tsunamis during prehistoric times.

Climatically, the study area is located in the sub-humid tropics with heavy rainfall during the summer monsoon and a dry period from December to February. Although the zone north of $5^{\circ} \mathrm{N}$ is generally characterised by the occurrence of tropical storms during the inter-monsoon periods (Pielke and Pielke, 1997), cyclone tracks in the Bay of Bengal are predominantly directed to the coasts of India, Bangladesh and Myanmar (Singh et al., 2000). For the eastern coast of the Andaman Sea, historical records show no landfall of a cyclone within the last $150 \mathrm{yr}$ (Murty and Flather, 2004). The tropical storm recorded closest to the study area was Cyclone Nargis in 2008, which hit the coastline of southern Myanmar $800 \mathrm{~km}$ to the north (Fritz et al., 2009).

\section{Previous studies on Phra Thong Island}

\subsection{Evidence of palaeotsunamis}

First palaeotsunamis on Phra Thong were identified by Jankaew et al. (2008) and Fujino et al. (2009). The former 

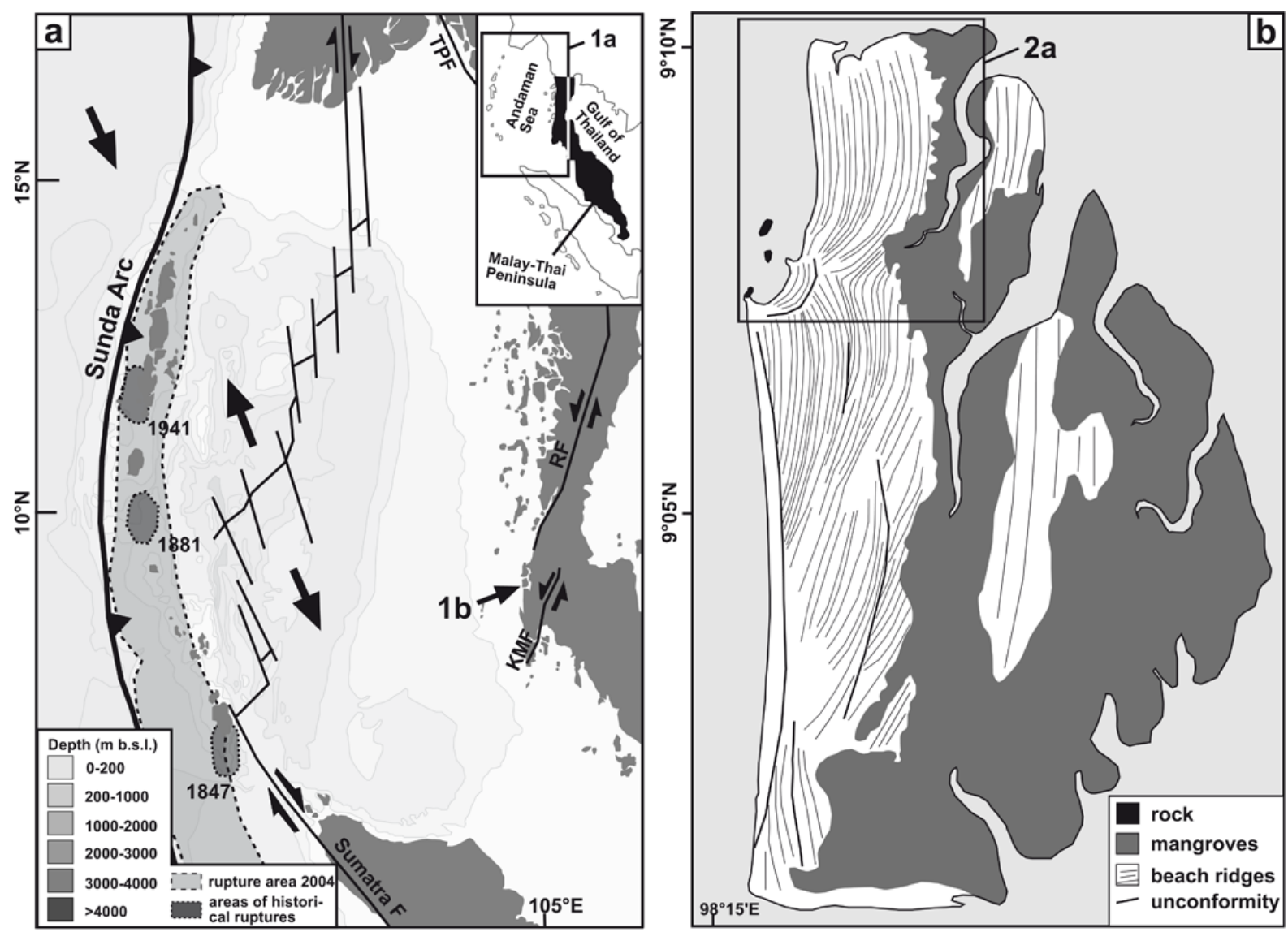

Fig. 1. Geographical and tectonic setting of the study area. (a) Tectonic structures of the Andaman Sea region (after Watkinson et al., 2008; KMF = Klong Marui Fault, RF = Ranong Fault, TPF = Three Pagodas Fault) with rupture areas of the 2004 megathrust (Subarya et al., 2006) and historical earthquakes (Bilham et al., 2005; Ortiz and Bilham, 2003) along the Andaman-Nicobar segment of the Sunda Arc. (b) Overview of Ko Phra Thong.

analysed two successive swales ca. $400 \mathrm{~m}$ east of the shoreline (swales $\mathrm{X}$ and Y, Fig. 2a). Above sandy intertidal deposits, a succession of peaty soils and sharply bounded sand sheets was observed. While swale $\mathrm{Y}$ contained three sand sheets below that of the IOT 2004, only two pre-2004 layers were detected in swale X. All sand sheets resembled the deposits of the IOT 2004 in their sedimentary characteristics, revealing thicknesses of 5-10 cm, a composition of chaotic or normal graded medium to very fine sand and sharp contacts to the peaty soils below, but lacked macro- and microfossils (Sawai et al., 2009). The sand sheets were assigned to prehistoric tsunami events, since landfalls of strong storms have not been reported; river runoff as well as aeolian dynamics can be excluded on Phra Thong, and sheet B chronologically correlates with tsunami evidence from Sumatra (Monecke et al., 2008). However, since the tsunamites were missing on the ridges, correlation between the layers of swale $\mathrm{X}$ and swale $\mathrm{Y}$ was not possible by other criteria than dating (Jankaew et al., 2008).
To determine ages for their tsunami deposits, Jankaew et al. (2008) used AMS- ${ }^{14} \mathrm{C}$ dating of macro-remains. While leaves taken from within the tsunami layers produced conflicting results, data of plant fragments from the confining peat limited the age of the younger layer to $550-700 \mathrm{cal} \mathrm{BP}$, and that of the older one to younger than 2200-2400 cal BP. In swale $Y$ the age of all three pre-2004 sand sheets could only be limited to younger than 2500-2800 cal BP (Jankaew et al., 2008). More detailed age information for these deposits is presented by Prendergast et al. (2012) in the form of luminescence data. While the OSL ages confirm the correlation of layer B between both swales $(350 \pm 50$ and $380 \pm 50 \mathrm{yr}$ ), a correlation of the older layers in swale $\mathrm{Y}$ $(2100 \pm 260$ and $990 \pm 130 \mathrm{yr})$ and swale X $(1410 \pm 190 \mathrm{yr})$ failed. Furthermore, the OSL ages of layer B are younger than expected from radiocarbon dating.

Fujino et al. (2009) analysed nine sediment cores from the northern part of the island (Fig. 2a), showing a similar stratigraphy with intertidal sand overlain by peaty soils and up to two discontinuous sand sheets older than 2004. These 

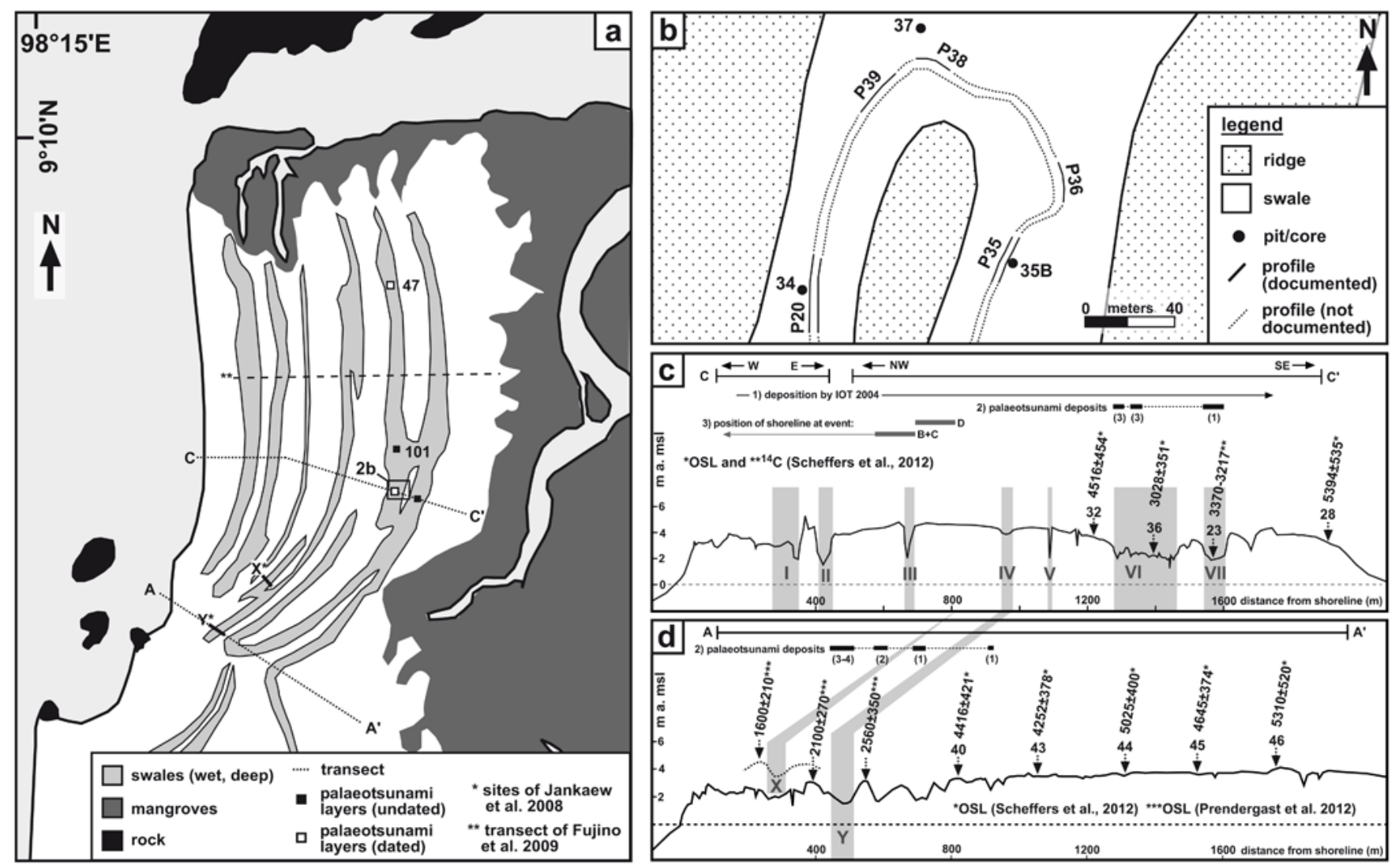

Fig. 2. Study area with sampling sites. (a) The north-western part of Phra Thong Island with the positions of deep and wet swales. Sampling sites of this and of previous studies are indicated. (b) Schematic overview of the southern section of swale VI (see a for exact location). (c) Topographical cross section in a west-east direction along transect $\mathrm{C}\left(\mathrm{C}-\mathrm{C}^{\prime}\right.$ in a) with position of swale VI and chronological data of the neighbouring beach ridges (Scheffers et al., 2012). (d) Topographical cross section along transect A with beach-ridge ages from Prendergast et al. (2012) and Scheffers et al. (2012).

could not be correlated laterally, not even by means of radiocarbon dating, since, different from Jankaew et al. (2008), bulk samples of peaty soil were used. Due to penetration of the sand layers and the soils by young roots, these ages (at least $1300 \mathrm{AD}$ and older $1900 \mathrm{AD}$ ) are likely to underestimate the real ages significantly.

Considering the low precision of the ages presented by Fujino et al. (2009), as well as the uncertainty of the luminescence ages of Prendergast et al. (2012), the only well confined ages for tsunami deposits on Phra Thong so far are slightly younger than $550-700 \mathrm{yr}$ for the youngest palaeotsunami and younger than $2500-2800 \mathrm{yr}$ for two or three older events (Jankaew et al., 2008). A correlation of layers across ridges based on these ages remains fragmentary.

\subsection{Holocene palaeogeography and sea levels}

Both sea level and palaeogeography at the time of impact are important for the interpretation of prehistoric tsunamis. Regarding Holocene sea-level changes on the west coast of
Thailand, model predictions of Horton et al. (2005) as well as field evidence of Scheffers et al. (2012) point to a high stand of $+2-3 \mathrm{~m}$ at 5-6 ka BP that was followed by a gradual regression to its present level, remaining below $+1 \mathrm{~m}$ during the last 3000 years. In contrast, there is little information about the Holocene coastal evolution of Phra Thong Island. Although chronological data for the formation of the beachridge plain in the form of OSL ages from Prendergast et al. (2012) for transect A (Fig. 2d) and Scheffers et al. (2012) for transects $\mathrm{A}$ and $\mathrm{C}$ (Fig. 2c and d) exist, it has not been used to discuss the shift in Holocene shorelines. Ridge ages of transect A, although with a poor resolution, cover the time from 5300 to $1600 \mathrm{yr}$ ago, and those of transect $\mathrm{C}$ reach from 5400 to $3000 \mathrm{yr}$ ago. Since each ridge and swale marks the position of a former shoreline, the correlation of these continuous structures between transects $\mathrm{A}$ and $\mathrm{C}$ allows for the approximate allocation of shorelines within the last $5500 \mathrm{yr}$ (Fig. 2c and d). 


\section{Methods}

\subsection{Stratigraphical methods}

The stratigraphical data presented in this paper were obtained from trenches and pits with maximum depths of $1.2 \mathrm{~m}$ below surface (b.s.). Since digging was limited by the high groundwater table, the trench and pit data were supported by closed sediment cores to document the sediments down to $1.75 \mathrm{mb}$.s. The profiles were photographed, described and sampled directly in the field. To establish an on-site facies stratigraphy, the sediment was characterised in terms of colour (Munsell Soil Color Charts), sedimentary structures and macrofossil remains. Grain size, sorting and carbonate content were estimated following Ad-hoc-Arbeitsgruppe Boden (2005). The topography of the study area was measured by means of a differential GPS (Leica SR 530) with less than $3 \mathrm{~cm}$ error.

Subsequently, selected reference profiles were sampled for laboratory measurements. Grain-size analyses were performed on dried fine-sediment samples $(<2 \mathrm{~mm})$ after treatment with $\mathrm{H}_{2} \mathrm{O}_{2}$ to remove organic matter using a laser particle sizer (Beckmann Coulter LS 13320). For the calculation of grain-size statistics (Method of Moments), the GRADISTAT software (Blott and Pye, 2001) was applied. Geochemical data include loss on ignition (LOI), determined by oven-drying at $105^{\circ} \mathrm{C}$ for $12 \mathrm{~h}$ and ignition at $550^{\circ} \mathrm{C}$ for $4 \mathrm{~h}$ (Beck et al., 1995). $\mathrm{CaCO}_{3}$ was measured by the Scheibler method. To establish a chronological framework for the stratigraphical setting and to cross-check the luminescence ages, macrofossil and plant remains from soil below and above the tsunami layers were AMS- ${ }^{14} \mathrm{C}$-dated. Measurements were carried out at the radiocarbon laboratory of the University of Georgia at Athens (USA). Calendar ages were calculated from conventional radiocarbon years by means of the OxCal 4.01 software using the IntCal09 calibration curves of Reimer et al. (2009). All radiocarbon ages in the text are presented in $2 \sigma$ sidereal years.

\subsection{Luminescence dating}

The optically stimulated luminescence technique (OSL) is based on the accumulation of a latent luminescence signal in certain mineral grains (typically quartz and potassium feldspar) due to the impact of ionising radiation in natural environments (decay of radioactive elements in the sediment and cosmic radiation) and the bleaching of this signal at exposure to sunlight (e.g. during sediment transport by wind or water). Thus, if luminescence signals are zeroed during transport, the accumulated signal at the time of sample extraction can be used to determine the time elapsed since the last transport cycle. The luminescence age is calculated by the formula: age $=$ palaeodose/dose rate, where the palaeodose is the amount of radiation in Gy needed to build up the luminescence signal accumulated during burial (by comparing the intensity of the OSL signal with the response to known laboratory doses), and the dose rate defines the amount of absorbed radiation in Gy per unit of time (see e.g. Aitken, 1998; Duller, 2004 or Preusser et al., 2008 for a detailed description of the method). In this study we applied OSL on quartz grains from tsunamigenic sand sheets to determine ages for prehistoric tsunami events.

The tsunami layers were sampled for palaeodose determination using opaque plastic tubes and were processed in subdued red light. Dried samples were sieved into separate grain-size fractions between 100 and $250 \mu \mathrm{m}$ and treated with $\mathrm{HCl}, \mathrm{H}_{2} \mathrm{O}_{2}$ and sodium oxalate to remove carbonate, organic material and clay. To obtain pure quartz, the sediment was separated with heavy liquid (2.58 and $\left.2.68 \mathrm{~g} \mathrm{~cm}^{-3}\right)$ and finally etched with concentrated HF (40\%) for $45 \mathrm{~min}$. All measurements were performed on a Ris $\emptyset$ TL/OSL DA 20 with a ${ }^{90} \mathrm{Sr} /{ }^{90} \mathrm{Y}$ beta source, delivering $0.0955 \mathrm{~Gy} \mathrm{~s}^{-1}$ to quartz grains at the sample position. Luminescence signals were detected through a Hoya U340 filter $(7.5 \mathrm{~mm})$ after blue LED stimulation, carried out at a temperature of $125^{\circ} \mathrm{C}$ for $50 \mathrm{~s}$. Small aliquots of $1 \mathrm{~mm}$ diameter - after Duller (2008) approximately 20-50 grains - were fixed on steel discs using silicon oil. Determination of equivalent doses $\left(D_{\mathrm{e}}\right)$ followed the SAR protocol of Murray and Wintle $(2000,2003)$ with three regenerative doses, zero measurement (recuperation), repetition of the first regenerative dose (recycling ratio) and test doses of $\sim 25 \%$ of the natural signal. The use of time integrals for the luminescence signal and the background subtraction followed the approach of Ballarini et al. (2007), with the background integral directly following the signal integral. Since this early background technique was designed to increase the percentage of the easily bleachable fast component, it provides general advantages for incompletely bleached samples. A ratio of 1:2.5 between signal length (0-0.4 s) and background length (0.4-1.4 s) was adopted from Cunningham and Wallinga (2010).

The effects of thermal pre-treatment were analysed by applying preheat plateau and thermal transfer tests. For this, the corrected OSL signal was measured in dependence of increasing preheat temperatures between $160^{\circ} \mathrm{C}$ and $280^{\circ} \mathrm{C}$ (after room temperature bleaching of the natural signal using blue LEDs in the case of the thermal transfer test). To guarantee the applicability of the samples for OSL dating, the recuperation and recycling ratios were analysed (Wintle and Murray, 2006). Additionally, we performed dose recovery tests with the laboratory radiation in the range of the natural doses. For the calculation of mean equivalent doses, the central age model (CAM), in case of well-bleached deposits, and the minimum age model (MAM), in case of incomplete bleaching, of Galbraith et al. (1999) were applied, whereas over-dispersion and the shape of $D_{\mathrm{e}}$ distributions were consulted to define the state of bleaching. The expected scatter, $\sigma_{\mathrm{b}}$, used for calculations with MAM, was taken from the average over-dispersion of well-bleached samples of the setting. 
Table 1. Dosimetry data of all samples. Depth $=$ depth below surface, $K=$ potassium content, $\mathrm{Th}=$ thorium content, $\mathrm{U}=$ uranium content, $\mathrm{W}=$ water content, $\mathrm{LOI}=$ loss on ignition, $\mathrm{D}=$ dose rate.

\begin{tabular}{lrcccccrr}
\hline Sample & $\begin{array}{r}\text { depth } \\
(\mathrm{cm})\end{array}$ & $\begin{array}{c}\mathrm{K} \\
(\%)\end{array}$ & $\begin{array}{l}\mathrm{Th} \\
(\mathrm{ppm})\end{array}$ & $\begin{array}{c}\mathrm{U} \\
(\mathrm{ppm})\end{array}$ & $\begin{array}{c}\text { grain size } \\
(\mu \mathrm{m})\end{array}$ & $\begin{array}{c}\mathrm{W} \\
(\%)\end{array}$ & $\begin{array}{r}\text { LOI } \\
(\%)\end{array}$ & $\begin{array}{c}\mathrm{D} \\
\left(\mathrm{Gy} \mathrm{kyr}^{-1}\right)\end{array}$ \\
\hline peat a. KPT 20/1 & 30 & $0.65 \pm 0.07$ & $75.8 \pm 3.0$ & $13.3 \pm 0.56$ & & 45.4 & 11.6 & \\
KPT 20/1 & 41 & $0.50 \pm 0.07$ & $86.8 \pm 3.5$ & $13.5 \pm 0.56$ & $125-200$ & 17.2 & 0.9 & 8.19 \\
peat a. KPT 20/2 & 45 & $0.63 \pm 0.07$ & $83.3 \pm 3.3$ & $12.1 \pm 0.51$ & & 21.1 & 5.5 & \\
KPT 20/2 & 50 & $0.71 \pm 0.17$ & $155.7 \pm 6.2$ & $19.7 \pm 0.84$ & $125-200$ & 18.5 & 0.8 & 12.02 \\
peat b. KPT 20/2 & 60 & $0.80 \pm 0.05$ & $26.9 \pm 1.1$ & $5.1 \pm 0.22$ & & 31.2 & 4.8 & \\
peat a. KPT 35/1 & 20 & $0.83 \pm 0.11$ & $114.0 \pm 4.6$ & $18.5 \pm 0.77$ & & 27.7 & 11.3 & \\
KPT 35/1 & 30 & $0.67 \pm 0.09$ & $101.4 \pm 4.1$ & $15.5 \pm 0.64$ & $125-200$ & 16.0 & 1.1 & 10.12 \\
peat a. KPT 35/2 & 36 & $0.94 \pm 0.09$ & $104.3 \pm 4.2$ & $15.7 \pm 0.65$ & & 17.3 & 4.2 & \\
KPT 35/2 & 43 & $1.03 \pm 0.12$ & $122.0 \pm 4.9$ & $17.3 \pm 0.72$ & $125-200$ & 18.3 & 0.8 & 11.52 \\
KPT 35/3 & 52 & $0.59 \pm 0.04$ & $13.7 \pm 0.5$ & $3.0 \pm 0.13$ & $125-200$ & 11.9 & 0.7 & 3.35 \\
peat b. KPT 35/3 & 60 & $0.62 \pm 0.05$ & $16.8 \pm 0.7$ & $6.5 \pm 0.27$ & & 18.1 & 4.5 & \\
KPT 37/1 & 24 & $0.71 \pm 0.09$ & $69.5 \pm 2.8$ & $11.3 \pm 0.47$ & $125-200$ & 20.6 & 1.6 & 6.8 \\
peat a. KPT 37/2 & 27 & $0.85 \pm 0.11$ & $84.0 \pm 3.3$ & $13.1 \pm 0.55$ & & 51.6 & 25.0 & \\
KPT 37/2 & 30 & $0.91 \pm 0.16$ & $138.2 \pm 5.5$ & $19.9 \pm 0.83$ & $125-200$ & 23.8 & 1.5 & 10.83 \\
peat b. KPT 37/2 & 40 & $0.78 \pm 0.12$ & $96.0 \pm 3.8$ & $14.9 \pm 0.62$ & & 29.8 & 18.6 & \\
peat a. KPT 47/1 & 12 & $0.65 \pm 0.05$ & $51.5 \pm 2.7$ & $9.2 \pm 0.41$ & & 42.0 & 12.1 & \\
KPT 47/1 & 20 & $0.61 \pm 0.09$ & $75.2 \pm 1.2$ & $11.7 \pm 0.32$ & $125-200$ & 20.0 & 0.9 & 7.33 \\
peat a. KPT 47/2 & 25 & $0.93 \pm 0.10$ & $74.0 \pm 3.0$ & $12.4 \pm 0.52$ & & 22.0 & 5.2 & \\
KPT 47/2 & 32 & $0.59 \pm 0.18$ & $64.8 \pm 2.6$ & $10.1 \pm 0.42$ & $125-200$ & 17.7 & 0.8 & 6.21 \\
peat a. KPT 47/3 & 38 & $0.22 \pm 0.04$ & $12.8 \pm 0.5$ & $3.5 \pm 0.15$ & & 19.5 & 4.3 & \\
KPT 47/3 & 50 & $0.19 \pm 0.02$ & $10.8 \pm 0.6$ & $2.9 \pm 0.14$ & $180-200$ & 17.0 & 1.2 & 1.61 \\
peat b. KPT 47/3 & 60 & $0.22 \pm 0.02$ & $15.5 \pm 0.7$ & $3.8 \pm 0.21$ & & 19.0 & 5.8 & \\
\hline
\end{tabular}

Dosimetry samples were taken from tsunamigenic sand sheets as well as the confining soil. The dose rate was calculated separately for the layers and the surrounding material from K, Th and U concentrations, measured via Neutron Activation Analyses at Becquerel Laboratories (Canada), and from in-situ water and organic carbon contents of the samples (after Madsen et al., 2005), using the layer model of the ADELE software (Kulig, 2005). The results are presented in Table 1.

\section{Results and discussion}

\subsection{Lithostratigraphy of swale VI}

Samples were taken from a deep and wet swale in the northern part of Phra Thong, approximately $1.3 \mathrm{~km}$ east of the present shoreline (swale VI, Fig. 2). The stratigraphy was documented along a $1.2 \mathrm{~km}$ long, south-north directed section of the swale. It is based on seven profiles, generated from trenches (KPT 20, 35, 36, 39 and 47) and pits (KPT 37 and 101), with core data being used to extend the stratigraphies of KPT 20 (core KPT 34), KPT 35 (core KPT 35B) and KPT 37 (core KPT 37B) even below groundwater level (Fig. 2a and b). Generally, all analysed profiles showed a similar succession of sediments (Fig. 3). Representative profiles of the typical stratigraphy (KPT 20/34) and the stratigraphy of the wettest sections (KPT 37) are presented in Sect. 5.1.1.

\subsubsection{Reference profiles KPT 20/34 and KPT 37}

Figure 4 shows the combined data of trench KPT 20 and core KPT 34. The base, from 1.20 to $0.71 \mathrm{~m}$ b.s., was composed of medium sand $($ mean $=260-570 \mu \mathrm{m})$ of light grey colour $(2.5 \mathrm{Y} 6 / 1)$ at the bottom and light greyish brown (2.5Y 5/2) towards the top. The sand contained wood fragments, but lacked fossils (in the same depositional unit of KPT 35, marine molluscs and coral fragments occurred where the deposits were situated below sea level; b.s.l.). The content of organic matter was low $(0.2-0.5 \%)$ and carbonate was absent. At $0.71 \mathrm{~m}$ b.s., a sharp contact separated the greyish sand from a succession of peaty soils and sand sheets (S1S4). The former were characterised by dark brown colour $(10 Y R 3 / 3)$, muddy sand (mean $=150-210 \mu \mathrm{m})$ with high amounts of organic carbon (5-12\%) and absence of $\mathrm{CaCO}_{3}$ or fossils. All peaty strata comprised densely packed modern and subrecent roots, but lacked macroscopic plant fragments (except for the uppermost peat at $0.33-0.11 \mathrm{~m}$ b.s.).

Common for the sand sheets were sharp contacts to the peaty soil below, moderate sorting and one or more graded subunits. S1 was light grey (10YR 6/1) and revealed a bimodal grain size composition, with peaks in the fine sand $(88-96 \mu \mathrm{m})$ and medium sand $(269-517 \mu \mathrm{m})$ fractions. 


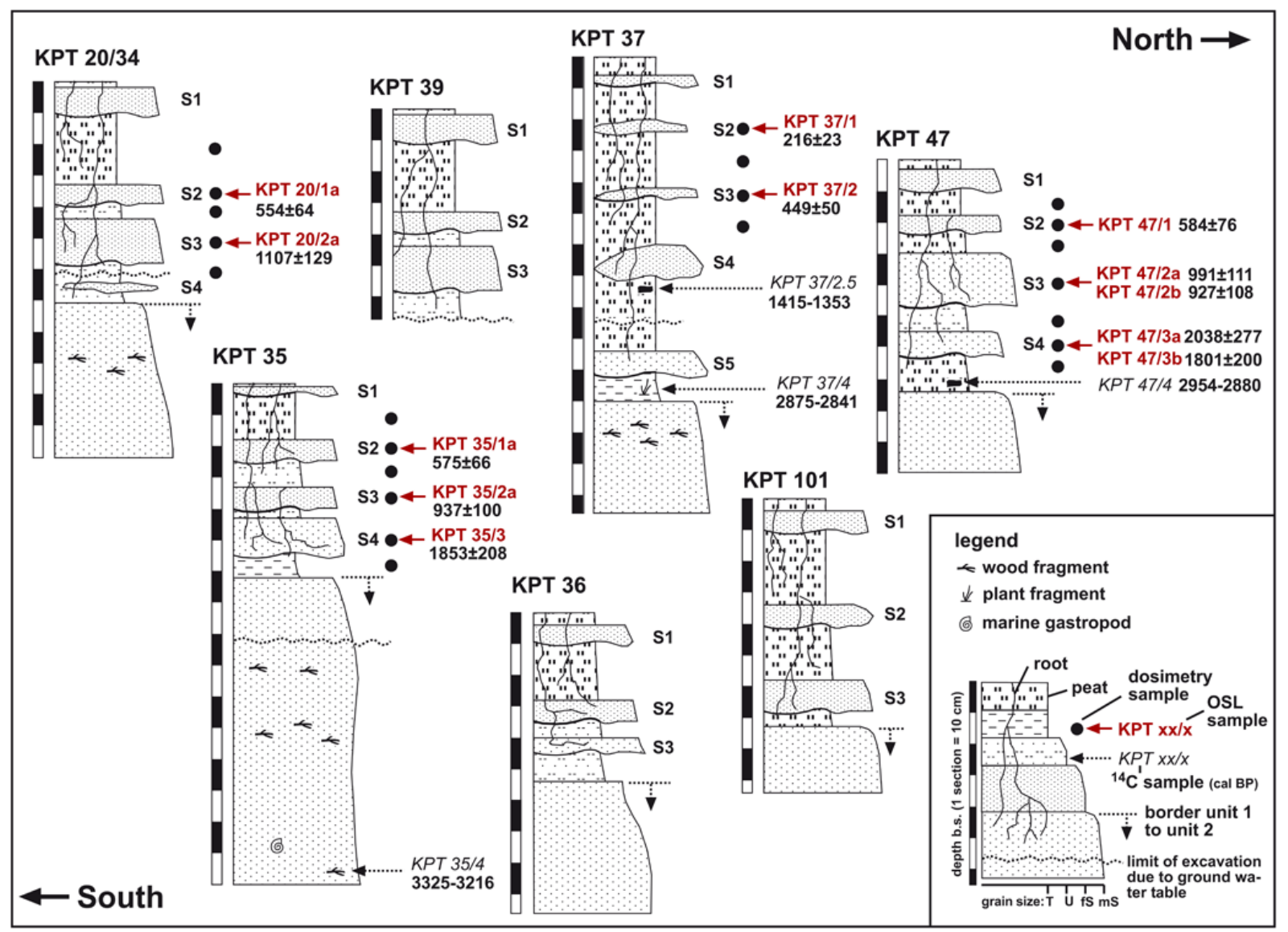

Fig. 3. Stratigraphy and chronology of all documented profiles.

Overall, it showed a fining-upward trend (mean $=190 \mu \mathrm{m}$ at the base to $100 \mu \mathrm{m}$ at the top), and was laterally continuous with a variable thickness of up to $10 \mathrm{~cm}$. Besides elevated concentrations of $\mathrm{CaCO}_{3}(8-15 \%)$ and decreased organics $(1.5-2.5 \%)$ compared to the confining soil, it contained small fragments of indefinable marine shells and muddy ripup clasts. All other layers (S2-S4) revealed a light greyish brown colour (10YR 6/2) and lacked carbonate as well as fossils. Their discontinuous lateral extends and the varying thicknesses were particularly prominent in trench KPT 20 (Fig. 4a and b). All three layers showed a bimodal composition of medium sand (269-324 and 517-567 $\mu \mathrm{m})$ and fine sand $(96.5-106 \mu \mathrm{m})$. While two fining-upward sequences were documented in $\mathrm{S} 2$, layers $\mathrm{S} 3$ and $\mathrm{S} 4$ revealed a massive structure. Similar to the soil strata, all sand sheets were penetrated by modern roots.

Compared to KPT 20/34, a slightly different stratigraphy was revealed in KPT 37 and KPT 101, located in the deepest parts of swale VI. The particularly wet conditions resulted in thicker and slightly better preserved peat strata; possibly due to bioturbation, the embedded sand sheets were extremely thin and discontinuous. The stratigraphical characteristics of KPT 37 are presented in Fig. 5: the base was composed of greyish brown (10YR 6/2), fine to medium sand void of carbonate and fossils. Macro-remains were restricted to occasional wood fragments. Above a sharp boundary at $1.10 \mathrm{~m}$ b.s. the sandy deposits were replaced by a succession of peaty soils and sand sheets. Compared to those of KPT 20/34, the very dark brown (10YR 2/2) peaty soils contained more organic matter (10-25\%) and were apparently thicker $(14-34 \mathrm{~cm})$. Embedded in the peaty soils, a total of five sand sheets, S1-S5, were distinguished: S1-S4 were exposed at the pit walls and characterised by discontinuous extents even over short distances (Fig. 5b). S5 was not reached by digging, but could be identified in the core (Fig. 5f). Laminated leaves at the top of S2 and S3 document the improved preservation conditions at this place (Fig. 5e). While S1 and S2 (Fig. 5d) contained carbonate (7-16\%) and small fossil fragments, $\mathrm{S} 3-\mathrm{S} 5$ lacked $\mathrm{CaCO}_{3}$.

\subsubsection{General stratigraphy and depositional environments}

The succession of deposits in swale VI resembles the one described by Jankaew et al. (2008) and Fujino et al. (2009). It can be divided into two sediment units: the basal part of 

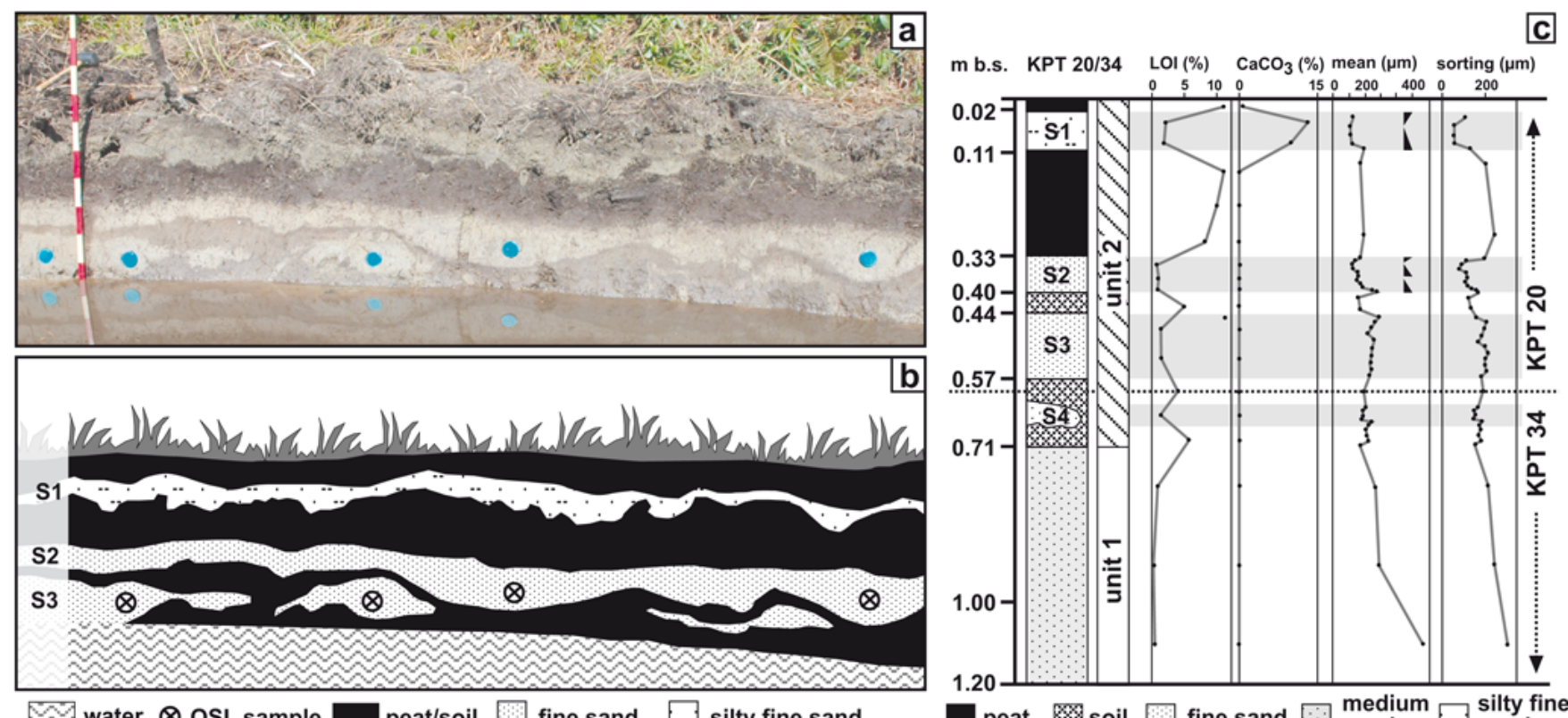

$\checkmark$ water $\otimes$ OSL sample

peat/soil

fine sand

silty fine sand

peat soil $\square$ fine sand $\rightarrow$ medium $\begin{aligned} & \text { silty fine } \\ & \text { sand }\end{aligned}$

Fig. 4. Combined stratigraphy of trench KPT 20 and core KPT 34 (see Fig. 2b for location). (a) Photograph of KPT 20. Each section of the scale represents $10 \mathrm{~cm}$. (b) Schematic profile of KPT 20 (sketch of the profile in a) with explanations of the sedimentary units. (c) Succession of sediments in profile KPT 20/34 with selected analytical parameters. The succession is representative for all other sites sampled in swale VI. S1-S4 = tsunami deposits.
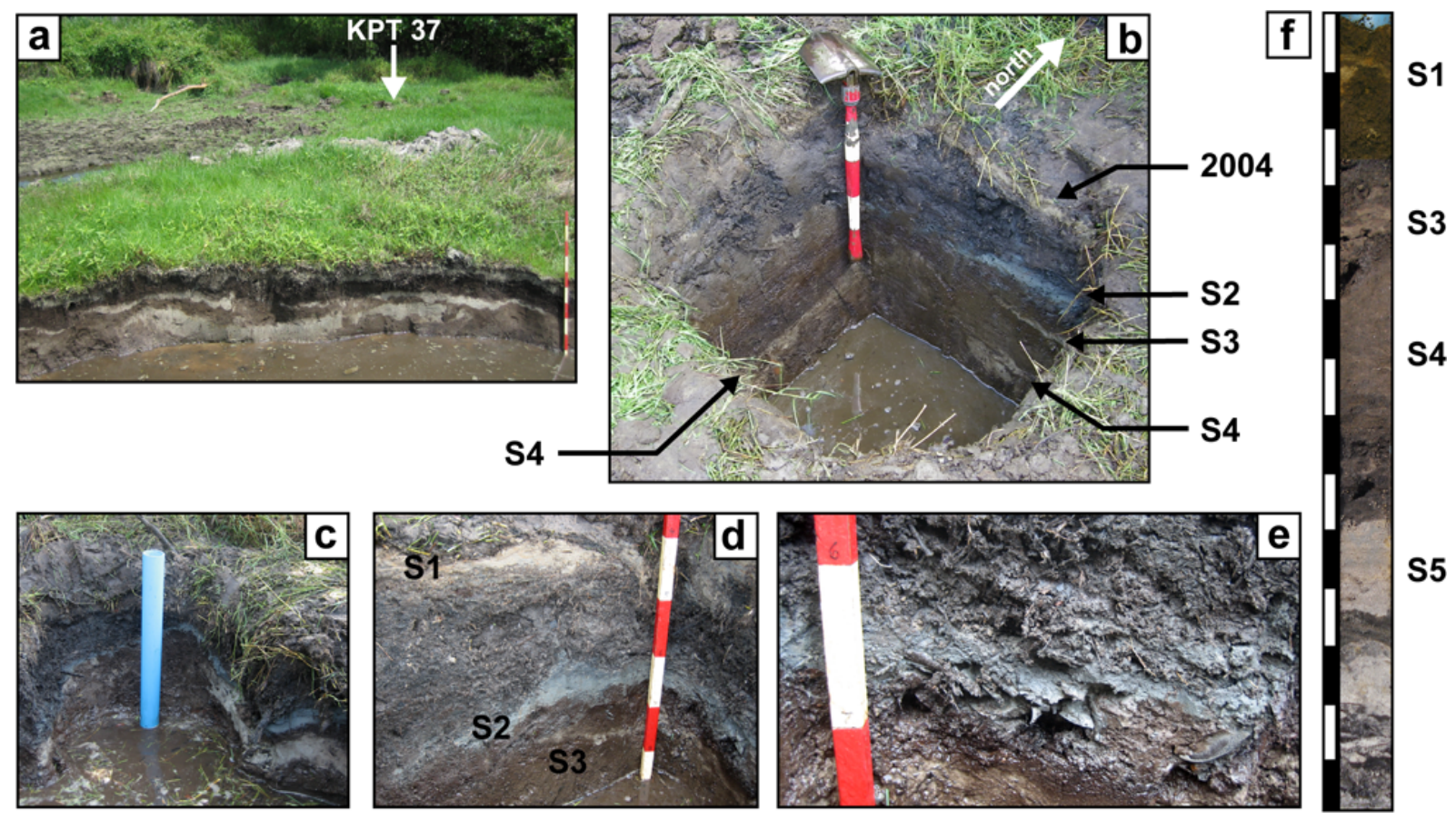

Fig. 5. The stratigraphy of KPT 37. (a) View from trench KPT 39 to the north with the location of pit KPT 37 . (b) Northern and western wall of pit KPT 37 with three discontinuous sand sheets below the IOT 2004 deposit (S2-4). (c) Core KPT 37B directly next to the pit. (d) Detail photograph of sand layers S1 and S2 (greenish grey); they appeared to be two separate layers. (e) Laminated leaves at the top of S2. (f) Sediment core KPT 37 extends the stratigraphy down to the intertidal sand of unit 1 (each segment of the scale represents $10 \mathrm{~cm}$ ). While layer S2 is missing in the core, an additional layer S5 is present. 
all profiles, i.e. the greyish sand below the sharp transitions at 0.71 and $1.10 \mathrm{mb}$ b. in KPT $20 / 34$ and 37 , respectively, was defined as unit 1 . All deposits above the contact, i.e. the sequence of alternating peaty soil and sand sheets, were summarised in unit 2. This succession was the same at all seven sites investigated in swale VI. However, the number of sand sheets in unit 2 as well as their thickness, sedimentary structure and granulometry were variable (Fig. 3). A maximum of five sand layers was observed in KPT 37 (S1-5). All other profiles contained either four (KPT 20/34, 35 and 47) or three sand sheets (KPT 36, 39 and 101).

While the greyish sand of unit 1 reflects deposition in an intertidal environment, the peat and soil strata of unit 2 were accumulated under swampy conditions inside the swales, after those had been separated from the sea by beach-ridge formation. The sand sheets reflect short interruptions of this environment by flooding events. The uppermost sand sheet (S1) was formed by the IOT in December 2004. All older layers (S2-5) revealed similar sedimentary characteristics as the IOT deposit; differences in geochemistry (zero instead of $8-15 \% \mathrm{CaCO}_{3}$ ), fossil content (no fossils in the older layers) and geometry (discontinuous extent) can be addressed to post-depositional changes (Szczuciński, 2012). Since the prehistoric sand sheets are interpreted to have the same origin as those described by Jankaew et al. (2008) and Fujino et al. (2009), they are referred to as tsunamites of unknown age (see Sect. 3, as well as Jankaew et al. (2008) for discussion). Some uncommon features of palaeotsunami deposits in swale VI were detected in S2 of KPT 37, which contained carbonate and fossils, a characteristic that can be observed for the 2004 deposit, but is missing in all palaeotsunami layers. Although the IOT deposit and S2 in KPT 37 were clearly developed as two separate layers (Fig. 5d), it might indicate that S2 is only a subunit of the 2004 deposit, which is separated by reworked plant debris. While the IOT deposit was present in all profiles throughout the swale, the extent of the palaeotsunami layers was laterally discontinuous and a correlation between distinct profiles based on the analysed sediment signatures was not possible.

\subsection{Dating tsunami deposits in swale VI}

\subsubsection{Radiocarbon dating}

Some limiting ages for the whole succession of tsunamigenic sand sheets are given by radiocarbon dating (Table 2): a wood fragment taken from the marine sand of unit 1 in KPT 35 gave an age of $3165-3345$ cal BP (UGAMS8050); charcoal from the basal peat in KPT 47 and plant fragments from the basal clay of KPT 37 provided ages of 2859-2991 cal BP (UGAMS-8053) and 2785-2923 cal BP (UGAMS-8051); additionally, another charcoal fragment from the top section of the peat between S4 and S5 in KPT 37 dated to 1345-1516 cal BP (UGAMS-8052).

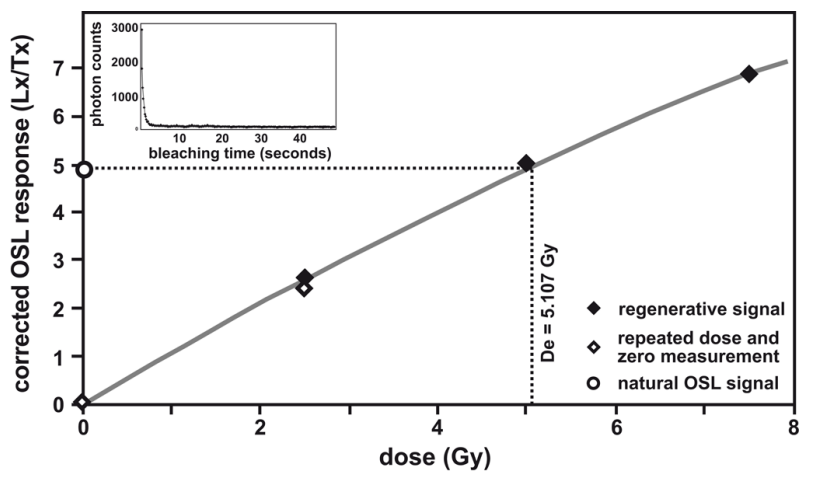

Fig. 6. Typical luminescence signal of the tsunamites of the study area (KPT 20/1a). Shine-down curve (upper left corner) and SAR growth curve.

\subsubsection{Luminescence dating}

Ten samples from sand sheets of four different profiles were taken for luminescence dating of the palaeotsunamis (Fig. 3): one sample each from the upper two palaeolayers of KPT 20 (KPT 20/1a and 20/2a) and KPT 37 (KPT 37/1 and 37/2), as well as from all three prehistoric sand sheets in KPT 35 (KPT 35/1a, 35/2a and 35/3). In case of KPT 47, the youngest palaeotsunami was sampled once, and sheets $\mathrm{S} 3$ and S4 twice (KPT 47/1; 47/2a, b and 47/3a, b). The shinedown and dose response curves (Fig. 6), as well as the results of laboratory experiments (Fig. 7) proved favourable luminescence properties for all samples: the dose recovery tests generated values with less than $5 \%$ difference between measured and given dose; the acceptance criteria regarding recycling ratio (0.90-1.10) and recuperation (less than $50 \mathrm{mGy}$ ) were missed by only $14 \%$ and $16.8 \%$, respectively (Fig. 7). Based on preheat plateau and thermal transfer tests, a preheat temperature of $220^{\circ} \mathrm{C}$ was selected for all samples.

Statistical analyses of the accepted aliquots (20-57 aliquots per sample) revealed three different types of $D_{\mathrm{e}}$ distributions (Fig. 8): (i) in case of KPT 20/1a, 20/2a, 35/1a, $35 / 3,37 / 2,47 / 2 a, 47 / 2 b, 47 / 3 a$ and 47/3b, the aliquots revealed unimodal, slightly over-dispersed $(6.3-15.6 \%)$ and positively skewed (0.5-2.1) $D_{\mathrm{e}}$ distributions (Fig. 8, type 1), indicating well-bleached material; (ii) KPT 35/2a and 47/1 were slightly over-dispersed (12.1-12.7\%), stronger positively skewed (2.2-2.8) and consisted of two $D_{\mathrm{e}}$ populations, of which the younger one accounted for the biggest part of the aliquots (Fig. 8, type 2). Although the over-dispersion is small, skewness and some higher $D_{\mathrm{e}}$ values (forming the second mode) point to a minor influence of partial bleaching; (iii) KPT 37/1 showed significantly higher over-dispersion $(28.2 \%)$ and was characterised by several $D_{\text {e }}$ populations (Fig. 8, type 3), indicating poor bleaching or sediment mixing. Taking the average over-dispersion of the well-bleached deposits, i.e. those with type $1 D_{\mathrm{e}}$ distributions, a $\sigma_{\mathrm{b}}$ value of $11 \%$ (the average of 6.3-15.6\%) was defined for age calculation with MAM. 
Table 2. Radiocarbon data from swale VI. All samples were measured in the Center for Applied Isotope Studies, University of Georgia, Athens (USA).

\begin{tabular}{|c|c|c|c|c|c|c|c|c|c|}
\hline $\begin{array}{l}\text { lab } \\
\text { code }\end{array}$ & sample & $\begin{array}{l}\text { depth } \\
\text { (cmb.s.) }\end{array}$ & material & $\begin{array}{r}\delta^{13} \mathrm{C} \\
(\% o)\end{array}$ & $\begin{array}{l}{ }^{14} \mathrm{C} \\
(\mathrm{BP})\end{array}$ & $\begin{array}{l}\text { sidereal yrs } \\
(\text { cal BP, } 2 \sigma)^{*}\end{array}$ & $\begin{array}{c}\text { sidereal yrs } \\
(\mathrm{cal} \mathrm{AD} / \mathrm{BC}, 2 \sigma)^{*}\end{array}$ & $\begin{array}{l}\text { sidereal yrs } \\
(\text { cal BP, } 1 \sigma)^{*}\end{array}$ & $\begin{array}{c}\text { sidereal yrs } \\
(\mathrm{cal} \mathrm{AD} / \mathrm{BC}, 1 \sigma)^{*}\end{array}$ \\
\hline UGAMS-8050 & KPT $35 / 4$ & 175 & wood fragment & -28.9 & $3040 \pm 25$ & $3345-3165$ & $1396-1216 \mathrm{BC}$ & $3325-3216$ & $1376-1267 \mathrm{BC}$ \\
\hline UGAMS-8051 & КРТ $37 / 4$ & 110 & plant fragment & -29.8 & $2760 \pm 20$ & $2923-2785$ & 974-836 BC & $2875-2841$ & 926-846 BC \\
\hline UGAMS-8052 & КРТ $37 / 2.5$ & 60 & plant fragment & -31.7 & $1520 \pm 25$ & $1516-1345$ & $435-605 \mathrm{AD}$ & $1415-1353$ & 535-597 AD \\
\hline UGAMS-8053 & KPT $47 / 4$ & 100 & charcoal & -26.7 & $2820 \pm 25$ & 2991-2859 & $1042-910$ BC & $2954-2880$ & $1005-931 \mathrm{BC}$ \\
\hline
\end{tabular}

* Calibrated ages calculated with IntCal09 (Reimer et al., 2009).
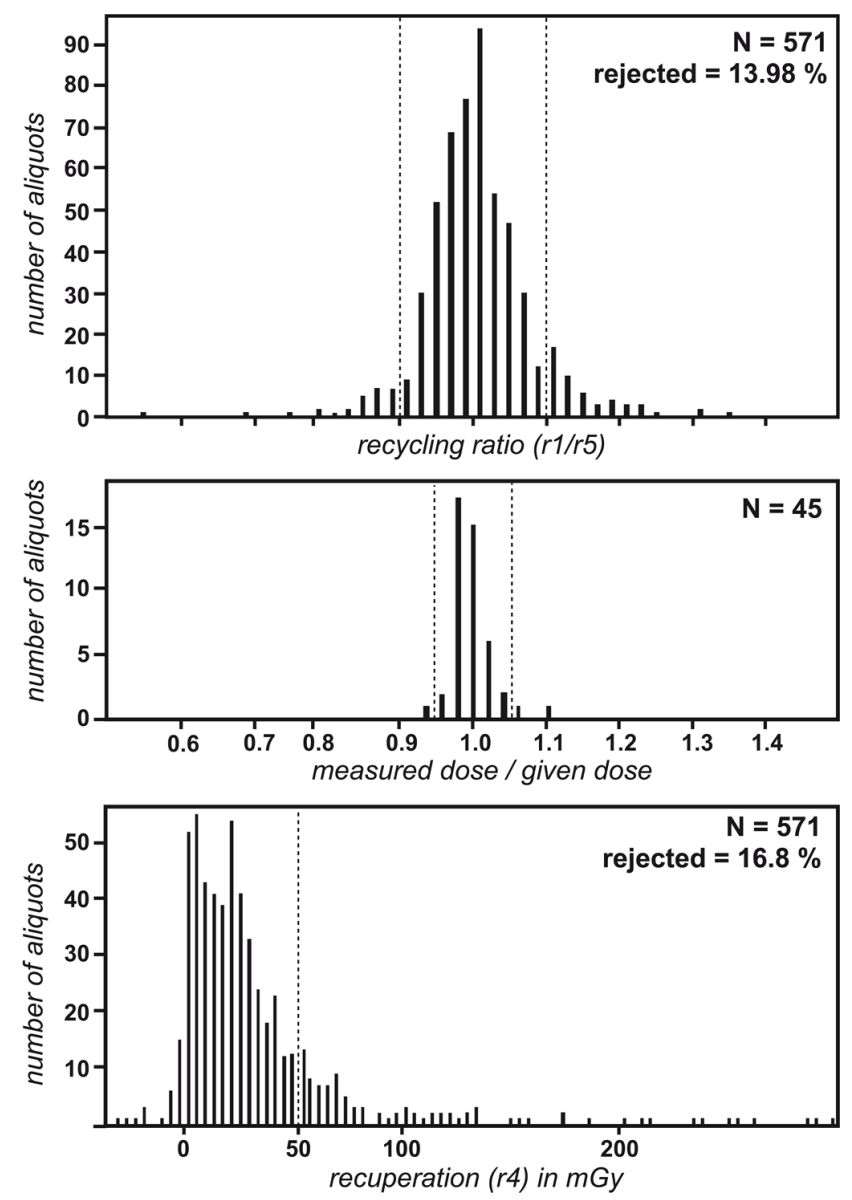

Fig. 7. Summary of recycling ratio, dose recovery and recuperation data of all samples. The dotted lines mark the limits of the acceptance criteria (recycling ratio: $0.9-1.1$, dose recovery: $0.95-$ 1.05, recuperation: $\leq 50 \mathrm{mGy}$ ). Only $14 \%$ of all measured aliquots (N) were rejected because of their recycling ratio and $16.8 \%$ due to their recuperation. Mean dose recovery values (computed from 4-5 aliquots per sample) all matched the acceptance criteria.

To determine mean $D_{\mathrm{e}}$ values for the incompletely bleached deposits (type 2 and $3 D_{\mathrm{e}}$ distributions), the minimum age model was applied. Since KPT 35/2a and KPT 47/1 (type 2) show characteristics more or less equal to deposits of the IOT 2004, which revealed minimised residuals of
28-40 yr using MAM compared to 53-83 yr using CAM (Brill et al., 2012), MAM should provide reliable ages. For KPT 37/1 (type 3), where multimodality and over-dispersion point to additional influence of sediment mixing during transport or after deposition, the results should be handled with care. In case of type $1 D_{\mathrm{e}}$ distributions, different from the modern analogue, the palaeotsunami deposits seem to be completely bleached. This discrepancy can be explained by the much older ages of the prehistoric tsunamites, since similar residuals like those observed for the IOT 2004 are small compared to the dating error of 500-2000 year old deposits. Thus, although it was demonstrated that MAM minimises the offset between expected age and OSL age for the IOT 2004 deposits (Brill et al., 2012), mean $D_{\mathrm{e}}$ values for the wellbleached samples (type 1) were calculated by CAM. Anyway, the differences between CAM and MAM-based ages are not significant (Table 3 ).

\subsubsection{The chronology of tsunami events}

The chronological framework of the deposits in swale VI is given by radiocarbon ages of the basal peat or clay in KPT 47 and KPT 37 (KPT 47/4 and 37/4) as well as from unit 1 in KPT 35 (KPT 35/4). While the latter dates the deposition of marine sand under intertidal conditions before swale VI was separated from the sea to $3165-3345$ cal BP, KPT 47/4 and KPT 37/4 provide ages of 2859-2991 cal BP and 2785-2923 cal BP for the period directly after the initiation of the swale by accumulation of the seaward beach ridge (Fig. 3). Simultaneously, they provide maximum limiting ages for the lowest palaeotsunami layer of each profile. All three ages are in good agreement and limit the deposition of all tsunamigenic sand sheets in swale VI to younger than 2800-3000 cal BP.

Direct ages for the palaeotsunami layers are provided by luminescence dating. These data are all younger than 2800$3000 \mathrm{yr}$ and, thus, agree with the limiting radiocarbon data. Furthermore, within the OSL ages of the same profiles, no inversions occur. The comparison of all data sets reveals three distinct time intervals with a clustering of layer ages (all ages of a cluster match within their errors; Fig. 9). The first cluster comprises the youngest palaeoevents in KPT 20, KPT 35 and KPT 47 as well as the second palaeolayer in KPT 37. The 


\section{type 1}
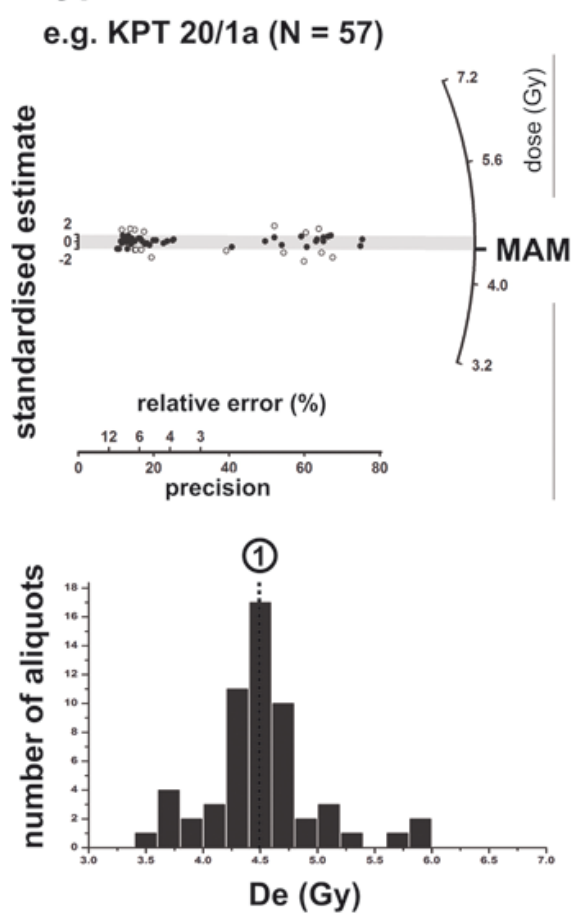

type 2

e.g. KPT 35/2a ( $N=57)$
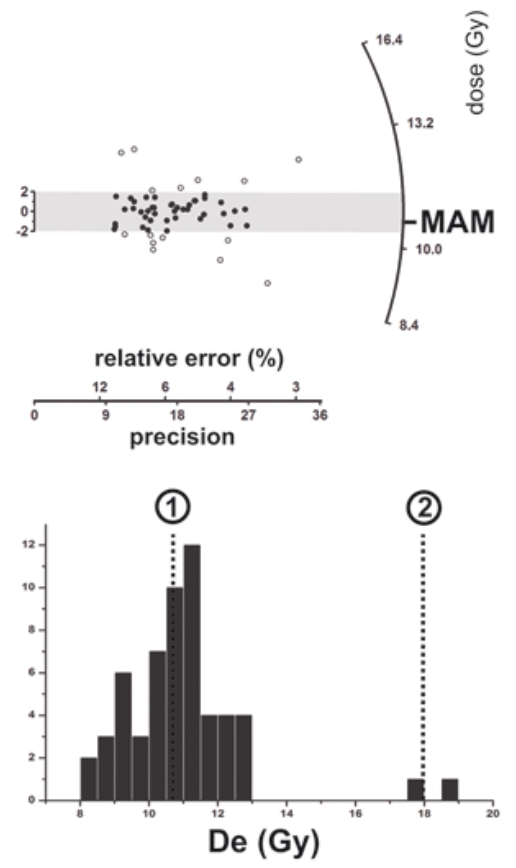

\section{type 3}

e.g. KPT $37 / 1$ ( $N=56)$
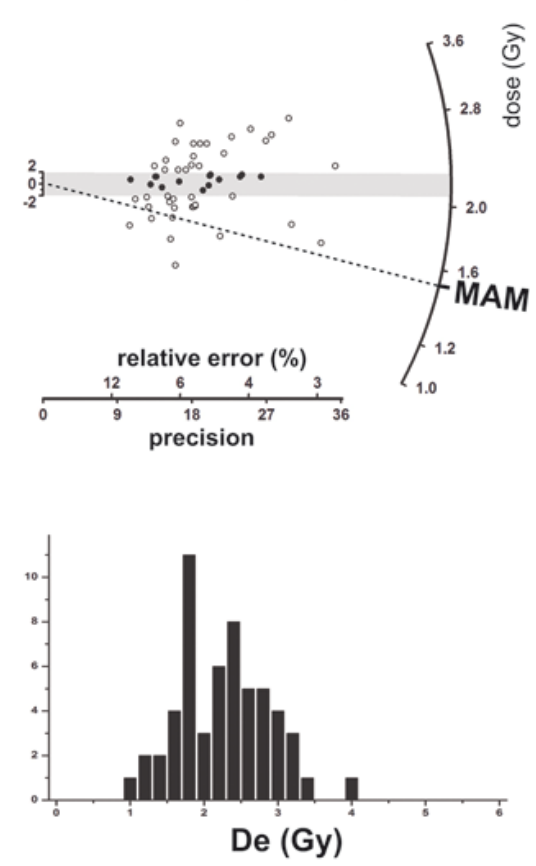

Fig. 8. The different types of $D_{\mathrm{e}}$ distribution. Grey shaded areas mark mean $D_{\mathrm{e}}$ values calculated with CAM. Encircled numbers indicate $D_{\mathrm{e}}$ populations.

Table 3. Summarised characteristics of the $D_{\mathrm{e}}$ distributions, mean equivalent doses, age models and ages for all samples (results of selected model in bold type). $\sigma_{\mathrm{b}}=$ expected scatter, skew. $=$ skewness, ovd.= over-dispersion, $D_{\mathrm{e}}$ pop. $=$ number of signal populations, $\mathrm{CAM}=$ central age model, $\mathrm{MAM}=$ minimum age model .

\begin{tabular}{lccccccccc}
\hline Sample & $\mathrm{N}$ & $\sigma_{\mathrm{b}}$ & skew. & ovd. & $\begin{array}{c}D_{\mathrm{e}} \\
\text { pop. }\end{array}$ & $\begin{array}{c}D_{\mathrm{e}} \mathrm{CAM} \\
(\mathrm{Gy})\end{array}$ & $\begin{array}{c}\text { age CAM } \\
\text { (years) }\end{array}$ & $\begin{array}{c}D_{\mathrm{e}} \text { MAM } \\
(\mathrm{Gy})\end{array}$ & $\begin{array}{c}\text { age MAM } \\
\text { (years) }\end{array}$ \\
\hline KPT 20/1a & 57 & 11 & 0.7 & 6.3 & 1 & $\mathbf{4 . 4 8} \pm \mathbf{0 . 1 8}$ & $\mathbf{5 5 4} \pm \mathbf{6 4}$ & $4.45 \pm 0.19$ & $552 \pm 68$ \\
KPT 20/2a & 40 & 11 & 0.7 & 11.1 & 1 & $\mathbf{1 4 . 1 2} \pm \mathbf{0 . 2 9}$ & $\mathbf{1 1 0 7} \pm \mathbf{1 2 9}$ & $12.52 \pm 0.37$ & $1044 \pm 122$ \\
KPT 35/1a & 55 & 11 & 1.1 & 10.9 & 1 & $\mathbf{5 . 7 2} \pm \mathbf{0 . 0 8}$ & $\mathbf{5 7 5} \pm \mathbf{6 6}$ & $5.67 \pm 0.28$ & $571 \pm 65$ \\
KPT 35/2a & 57 & 11 & 2.2 & 12.1 & 2 & $10.85 \pm 0.17$ & $941 \pm 102$ & $\mathbf{1 0 . 6 6} \pm \mathbf{0 . 2 2}$ & $\mathbf{9 3 7} \pm \mathbf{1 0 0}$ \\
KPT 35/3 & 39 & 11 & 1.8 & 10.1 & 1 & $\mathbf{6 . 1 6} \pm \mathbf{0 . 1 2}$ & $\mathbf{1 8 5 3} \pm \mathbf{2 0 8}$ & $6.08 \pm 0.11$ & $1837 \pm 201$ \\
KPT 37/1 & 56 & 11 & 0.3 & 28.2 & & $2.17 \pm 0.09$ & $319 \pm 36$ & $\mathbf{1 . 4 7} \pm \mathbf{0 . 0 9}$ & $\mathbf{2 1 6} \pm \mathbf{2 3}$ \\
KPT 37/2 & 38 & 11 & 1.4 & 15.6 & 1 & $\mathbf{4 . 8 5} \pm \mathbf{0 . 1 1}$ & $\mathbf{4 4 9} \pm \mathbf{5 0}$ & $4.58 \pm 0.21$ & $440 \pm 47$ \\
KPT 47/1 & 40 & 11 & 2.8 & 12.7 & 2 & $4.14 \pm 0.14$ & $594 \pm 75$ & $\mathbf{4 . 0 7} \pm \mathbf{0 . 0 9}$ & $\mathbf{5 8 4} \pm \mathbf{7 6}$ \\
KPT 47/2a & 42 & 11 & 2.1 & 11.4 & 1 & $\mathbf{6 . 1 6} \pm \mathbf{0 . 1 2}$ & $\mathbf{9 9 1} \pm \mathbf{1 1 1}$ & $6.08 \pm 0.11$ & $988 \pm 110$ \\
KPT 47/2b & 22 & 11 & 1.1 & 13.2 & 1 & $\mathbf{5 . 7 6} \pm \mathbf{0 . 1 7}$ & $\mathbf{9 2 7} \pm \mathbf{1 0 8}$ & $5.62 \pm 0.28$ & $916 \pm 103$ \\
KPT 47/3a & 33 & 11 & 0.8 & 12.8 & 1 & $\mathbf{3 . 3 3} \pm \mathbf{0 . 0 8}$ & $\mathbf{2 0 3 8} \pm \mathbf{2 7 7}$ & $3.18 \pm 0.21$ & $2028 \pm 273$ \\
KPT 47/3b & 20 & 11 & 0.5 & 13.4 & 1 & $\mathbf{3 . 0 8} \pm \mathbf{0 . 1 1}$ & $\mathbf{1 8 0 1} \pm \mathbf{2 0 0}$ & $2.81 \pm 0.29$ & $1794 \pm 198$ \\
\hline
\end{tabular}

second palaeolayers in KPT 20, KPT 35 and KPT 47 fall into the second cluster. Cluster three aggregates the oldest event deposits in KPT 35 and KPT 47.

Each cluster is related to a single tsunami event. Thus, additionally to the IOT 2004, which is defined as event A, we found deposits of at least three older tsunamis, namely events B, C and D, with ages of 400-660 yr (1610-1350 AD),
$820-1230 \mathrm{yr}(1190-780 \mathrm{AD})$ and $1600-2300 \mathrm{yr}(410 \mathrm{AD}$ to 290 BC), respectively (light shaded areas in Fig. 9). Their impacts can be timed more precisely by using the weighted mean of all ages inside a cluster (dark shaded areas in Fig. 9); this way, events B, C and D are dated to 492-554 yr (1518$1456 \mathrm{AD}), 925-1035 \mathrm{yr}(1085-975 \mathrm{AD})$ and $1743-1999 \mathrm{yr}$ (267-11 AD). A potential fourth event $\mathrm{X}$ is present solely in 


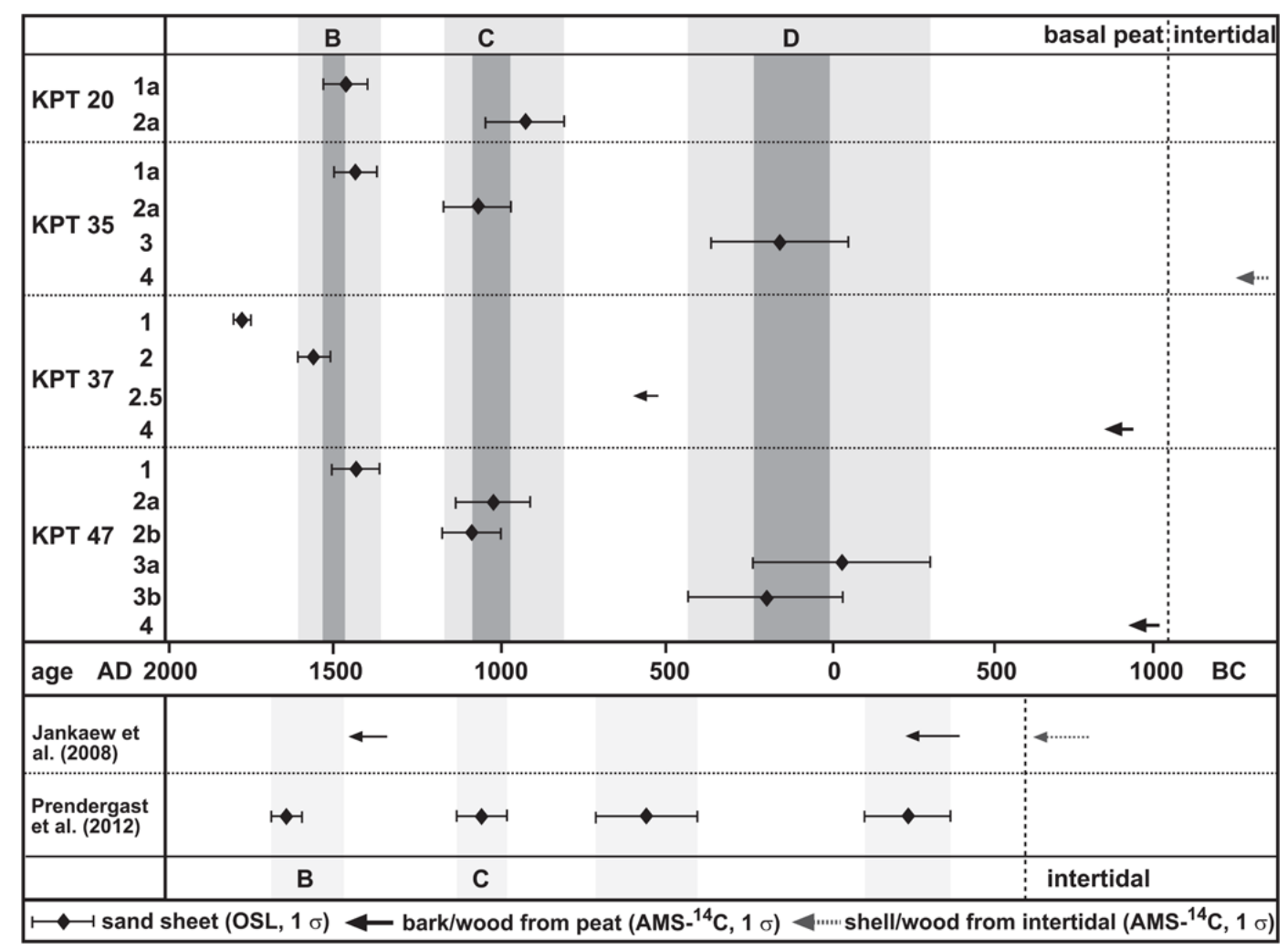

Fig. 9. Age plot of all dated profiles in swale VI (upper part) in relation to the results of other studies (lower part). The comparison of the four different profiles of swale VI shows that the layer ages cluster within intervals at 400-660 (B), 820-1230 (C) and 1600-2300 (D) years (light grey areas). The dark grey areas indicate the weighted mean of all ages inside a cluster. Each cluster is related to one palaeotsunami event (B, C, D).

KPT 37, where it is located between the deposits of the IOT and event B. Although it was dated to an age of 193-239 yr (1817-1771 AD) and luminescence dating of the modern 2004 tsunami deposits on Phra Thong showed much smaller offsets of less than $50 \mathrm{yr}$ (Brill et al., 2012), we cannot rule out the possibility that it is part of the 2004 deposit (as stated in Sect. 5.1.2 it might be a sublayer of the IOT deposit), particularly, since a similar layer is missing at all other sites in swale VI (as well as in other swales on Phra Thong). The only possible counterpart mentioned in historical records is the $1762 \mathrm{AD}$ earthquake off Myanmar (Dominey-Howes et al., 2007), which is considered unlikely to have generated a tsunami strong enough to inundate Phra Thong Island (Okal and Synolakis, 2008).

\subsection{Correlation of palaeotsunami deposits}

\subsubsection{Intra-swale correlation}

Based on luminescence ages and radiocarbon data, we correlated the distinct sand sheets in the profiles of swale VI with events B, C and D. This way, it was possible to trace the deposits of all three events from KPT 20 in the south to KPT 47 in the north (Fig. 10). While this is confirmed by OSL ages for KPT 20, KPT 35, KPT 37, and KPT 47, in the case of the undated profiles KPT 39 and KPT 36, the correlation is based on visual extrapolation from layers of neighbouring profiles. Additionally, for the third palaeolayer in KPT 37, the correlation with event $\mathrm{C}$ is supported by the radiocarbon date of $1345-1516$ cal BP from the peat below, which is too old for event B and too young for event D. Only in KPT 101, which is undated and spatially isolated from the nearest profiles, none of the two sand sheets can be related with certainty. Besides chronological data, the concentrations of ${ }^{232} \mathrm{Th}$ and ${ }^{238} \mathrm{U}$ (which were measured for dose rate determination; Table 1) may function as another indicator to correlate the sand sheets. The thorium concentrations show a sharp decline directly below event layer $\mathrm{C}$ in all measured profiles (KPT 20, 35 and 47; Fig. 10); thus, the border between events $C$ and $\mathrm{D}$ forms a significant marker, which can be identified by radionuclide analysis.

\subsubsection{Inter-swale correlation}

Considering the overall successful correlation of sand layers in swale VI, we related events B, C and D with precisely dated counterparts in other swales on the island as well; the youngest palaeotsunami of Jankaew et al. (2008) 


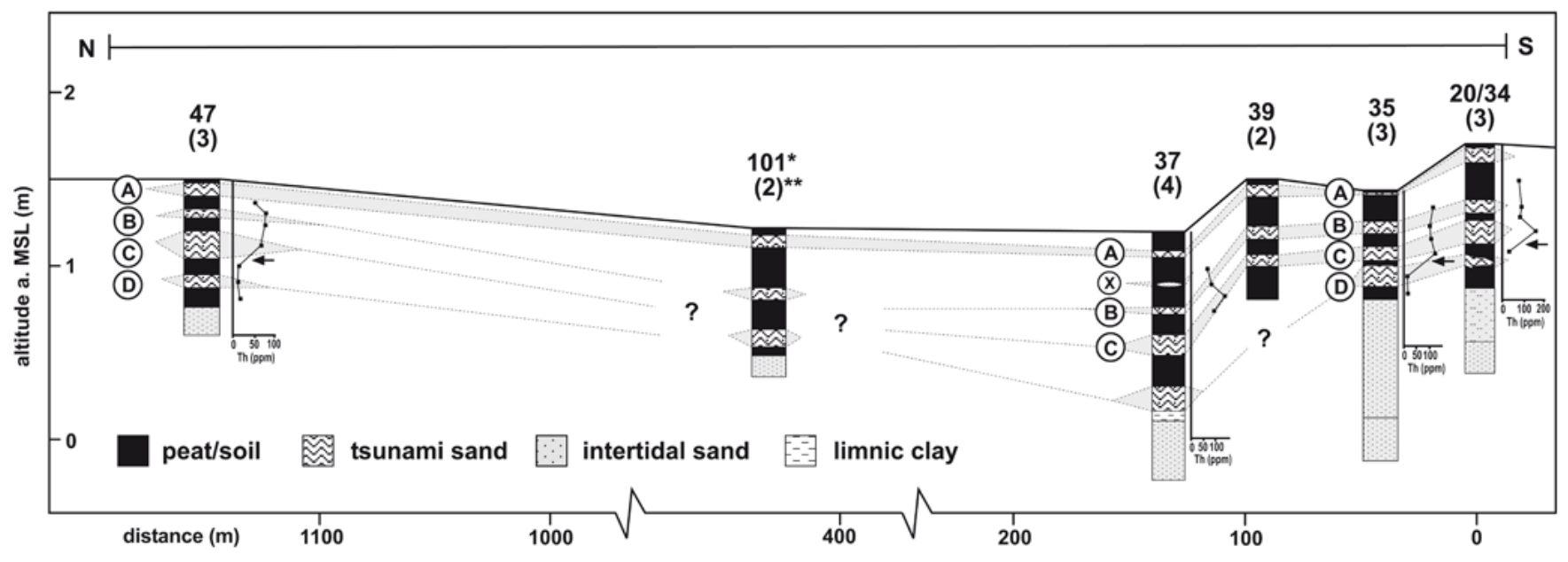

Fig. 10. Spatial correlation of palaeotsunami deposits A, B, C, D and X between the different sites in swale VI based on chronological data. * ID of the profile, e.g. KPT 101; ** number of palaeotsunami layers.

with an age slightly younger than $1450-1300 \mathrm{AD}$, correlates with the 492-554 yr old (1518-1456 AD) layer B of swale VI. Two or three older events are definitely younger than $500-800 \mathrm{BC}$ and could therefore be counterparts of layer C (1085-975 AD) and layer D (267-11 AD) in swale VI. The OSL data of Prendergast et al. (2012) for these layers suggest ages of $990 \pm 130 \mathrm{yr}(1140-980 \mathrm{AD}), 1410 \pm 190 \mathrm{yr}$ (780-400 AD) and $2100 \pm 260 \mathrm{yr}(160 \mathrm{AD}-360 \mathrm{BC})$. While the youngest date matches precisely the age of event $\mathrm{C}$, a correlation of event $\mathrm{D}$ with one of the other layers is not possible.

Taking the boundary conditions at the time of impact in the form of water level and palaeogeography into account, additional information about minimum inundation distances can be obtained. While the tide level at the time of prehistoric tsunami impacts is not determinable, the sea level was $<1 \mathrm{~m}$ above present for all three events, an insignificant value compared to the tidal range of $2.5 \mathrm{~m}$ (Scheffers et al., 2012). Similarly, the palaeotopography has changed only little during the last two millennia, since palaeosol formation and the effects of the IOT 2004 document rather stable ridge heights (Scheffers et al., 2012). Solely the position of the shoreline has changed significantly during the last $2000 \mathrm{yr}$. By correlating the undated ridges and swales of transect $C$ with dated counterparts in transect A (swale X that marks the $2500 \mathrm{BP}$ shoreline is identical with swale IV in transect $\mathrm{C}$, and swale $\mathrm{Y}$, which indicates the coastline at $2000 \mathrm{BP}$, is located between swales III and IV of transect C), approximate shoreline positions in transect $\mathrm{C}$ can be estimated for events $\mathrm{B}, \mathrm{C}$ and D (Fig. 2c): $1800 \mathrm{yr}$ ago, when event $\mathrm{D}$ hit the island, the shoreline was directly east of swale III $(\sim 500 \mathrm{~m}$ west of swale VI), and during events B and C it was somewhere west of swale III (at least $600 \mathrm{~m}$ west of swale VI). This implies minimum inundation distances of $500 \mathrm{~m}$ for event $\mathrm{D}$, and at least $600 \mathrm{~m}$ (probably much more) for events B and C.

\subsubsection{Basin wide correlation}

In a wider geographical context - i.e. by considering the coasts of all countries affected by the IOT 2004 - counterparts for events B, C and D exist as well. The youngest palaeotsunami of 1518-1456 AD is supported by sedimentary evidence from Ban Bang Sak (1450-1250 AD; Brill et al., 2011) and Krabi (1425-1410 AD; Harper, 2005) in Western Thailand, Sumatra (younger than 1400-1290 AD; Monecke et al., 2008) and the Andaman Islands (younger than 1300-1200 AD; Malik et al., 2010). Contemporaneous evidence for the 1085-975 AD tsunami (event C) is postulated from Sumatra (younger than 990-780 AD; Monecke et al., 2008), Sri Lanka (ca. 1000 AD; Ranasinghage et al., 2010) and Eastern India (ca. 1000 AD; Rajendran et al., 2006). Additionally, for both periods (when events B and C took place, respectively), uplifted corals on the Andaman Islands and in Northern Sumatra (uplift comparable or bigger than 2004) prove strong ruptures of the Sunda Fault (ca. 1450 AD and 1000 AD; Rajendran et al., 2008; Meltzner et al., 2010). The oldest palaeotsunami of Phra Thong, event D, is less well supported by evidence from other locations. The only comparatively contemporaneous evidence is provided by possible tsunami deposits from Thailand (Brill et al., 2011) and Eastern India (Rajendran et al., 2006).

\section{Conclusions}

The study shows that in absence of appropriate material for radiocarbon dating, the optically stimulated luminescence technique can be successfully applied to improve the knowledge about palaeotsunami frequencies. On Phra Thong Island, the luminescence data revealed three prehistoric tsunami events prior to the IOT 2004 (event A): event B took place $490-550 \mathrm{yr}$ ago, event $\mathrm{C} 925-1035 \mathrm{yr}$ ago and event $\mathrm{D}$ occurred between 1740 and $2000 \mathrm{yr}$ ago. A possible 
fourth palaeotsunamite, dated to $190-240 \mathrm{yr}$, is most probably only a poorly bleached sublayer of the 2004 tsunami deposit. Besides their contribution to a better event chronology of the region, the luminescence ages also enable the correlation of various distinct tsunami deposits on the island; although discontinuous, events $\mathrm{B}, \mathrm{C}$ and $\mathrm{D}$ could be traced at spatially separated sites within a single swale, as well as across beach ridges. For at least two palaeotsunamis (events B and C), dated counterparts in swales $500 \mathrm{~m}$ apart exist and, thus, give information about minimum inundation distances. Furthermore, the OSL ages enable correlation with contemporaneous tsunami evidence from other coasts around the Indian Ocean for all three palaeoevents, which can be used as another indicator for the magnitude of the tsunamis.

Acknowledgements. This study was carried out under the umbrella of the Thai-German cooperation TRIAS (Tracing Tsunami Impacts On- and Offshore in the Andaman Sea Region), financially supported by NRCT (National Research Council of Thailand) (ref. no.: GE3/2554) and DFG (German Research Foundation) (DFG ref. nos.: PAK 228; BR 877/27-1, -2; KE 190/26-1), which is gratefully acknowledged. We appreciate the administrative and logistic support by Penjai Sompongchaiyakul, Suratta Bunsomboonsakul (Chulalongkorn University, Bangkok) and Klaus Schwarzer (University of Kiel, Germany). We thank Thanakorn Jiwarungruangkul for help during field work on Phra Thong Island and Kirstin Jacobson for language editing. Jakob Wallinga, Adam Switzer and Giuseppe Mastronuzzi provided constructive remarks during the review process.

Edited by: K. Schwarzer

Reviewed by: J. Wallinga, G. A. Mastronuzzi, and A. Switzer

\section{References}

Ad-hoc-Arbeitsgruppe Boden der Staatlichen Geologischen Dienste und der Bundesanstalt für Geowissenschaften und Rohstoffe (Eds.): Bodenkundliche Kartieranleitung, Schweizerbart, Stuttgart, 2005.

Aitken, M. J.: An introduction to optical dating, Oxford University Press, 267 pp., 1998.

Atwater, B. F.: Evidence for great Holocene earthquakes along the outer coast of Washington State, Science, 236, 942-944, 1987.

Ballarini, M., Wallinga, J., Wintle, A. G., and Bos, A. J. J.: A modified SAR protocol for optical dating of individual grains from young quartz samples, Radiat. Meas., 42, 360-369, 2007.

Banerjee, D., Murray, A. S., and Foster, I. D. L.: Scilly Isles, UK: optical dating of a possible tsunami deposit from the 1755 Lisbon earthquake, Quaternary Sci. Rev., 20, 715-718, 2001.

Bilham, R., Engdahl, E. R., Feldl, N., and Satyabala, S. P.: Partial and complete rupture of the Indo-Andaman plate boundary 1847-2004, Seismol. Res. Lett., 76, 299-311, 2005.

Bishop, P., Sanderson, D., Hansom, J., and Chaimanee, N.: Agedating of tsunami deposits: lessons from the 26 December 2004 tsunami in Thailand, Geograph. J., 171, 379-384, 2005.
Blott, S. J. and Pye, K.: GRADISTAT: A grain size distribution and statistics package for the analysis of unconsolidated sediments, Earth Surf. Proc. Land., 26, 1237-1248, 2001.

Brill, D., Brückner, H., Jankaew, K., Kelletat, D., Scheffers, A., and Scheffers, S.: Potential predecessors of the 2004 Indian Ocean Tsunami - sedimentary evidence of extreme wave events at Ban Bang Sak, SW Thailand, Sediment. Geol., 239, 146-161, 2011.

Brill, D., Klasen, N., Brückner, H., Jankaew, K., Scheffers, A., Kelletat, D., and Scheffers, S.: OSL dating of tsunami deposits from Phra Thong Island, Thailand, Quat. Geochronol., doi:10.1016/j.quageo.2012.02.016, 2012.

Choowong, M., Murakoshi, N., Hisada, K., Charusiri, P., Doarerk, V., Charoentitirat, T., Chutakositkanon, V., Jankaew, K., and Kanjanapayont, P.: Erosion and deposition by the 2004 Indian Ocean tsunami in Phuket and Phang-nga provinces, Thailand, J. Coast. Res., 23, 1270-1276, 2007.

Cisternas, M., Atwater, B. F., Torrejón, F., Sawai, Y., Machuca, G., Lagos, M., Eipert, A., Youlton, C., Salgado, I., Kamataki, T., Shishikura, M., Rajendran, C. P., Malik, J. K., Rizal, Y., and Husni, M.: Predecessors of the giant 1960 Chile earthquake, Nature, 437, 404-407, 2005.

Cunha, P., Buylaert, J. P., Murray, A. S., Andrade, C., Freitas, M. C., Fatela, F., Munha, J. M., Martins, A. A., and Sugisaki, S.: Optical dating of clastic deposits generated by an extreme marine coastal flood: The 1755 tsunami deposits in the Algarve (Portugal), Quat. Geochronol., 5, 329-335, 2010.

Cunningham, A. C. and Wallinga, J.: Selection of integration time intervals for quartz OSL decay curves, Quat. Geochronol., 5, 657-666, 2010.

Dahanayake, K. and Kulasena, N.: Recognition of diagnostic criteria for recent- and paleo-tsunami sediments from Sri Lanka, Mar. Geol., 254, 180-186, 2008.

Dawson, A. G. and Stewart, I.: Tsunami deposits in the geological record, Sediment. Geol., 200, 166-183, 2007.

Dawson, A. G., Long, D., and Smith, D. E.: The Storegga slides: Evidence from eastern Scotland for a possible tsunami, Mar. Geol., 82, 271-276, 1988.

Dominey-Howes, D., Cummins, P., and Burbidge, D.: Historic records of teletsunami in the Indian Ocean and insights from numerical modelling, Nat. Hazards, 42, 1-17, 2007.

Duller, G. A. T.: Luminescence dating of Quaternary sediments: recent advances, J. Quaternary Sci., 19, 183-192, 2004.

Duller, G. A. T.: Single-grain optical dating of Quaternary sediments: why aliquot size matters in luminescence dating, Boreas, 37, 589-612, 2008.

Engel, M., Brückner, H., Wennrich, V., Scheffers, A., Kelletat, D., Vött, A., Schäbitz, F., Daut, G., Willershäuser, T., and May, S. M.: Coastal stratigraphies of eastern Bonaire (Netherlands Antilles): New insights into the palaeo-tsunami history of the southern Caribbean, Sediment. Geol., 231, 14-30, 2010.

Fagherazzi, S. and Du, X.: Tsunamigenic incisions produced by the December 2004 earthquake along the coasts of Thailand, Indonesia and Sri Lanka, Geomorphology, 99, 120-129, 2008.

Fritz, H. M., Blount, C. D., Thwin, S., Kyaw Thu, M., and Chan, N.: Cyclone Nargis storm surge in Myanmar, Nat. Geosci., 2, 448-449, 2009.

Fujino, S., Naruse, H., Matsumoto, D., Jarupongsakul, T., Sphawajruksakul, A., and Sakakura, N.: Stratigraphic evidence for pre2004 tsunamis in south-western Thailand, Mar. Geol., 262, 25- 
$28,2009$.

Galbraith, R. F., Roberts, R. G., Laslett, G. M., Yoshida, H., and Olley, J. M.: Optical dating of single grains of quartz from Jinmium rock shelter, northern Australia, Part I: experimental design and statistical models, Archaeometry, 41, 339-364, 1999.

Harper, S. B.: Bedded shell deposit at Ao Nang, Krabi Province, southern Thailand: A record of a prehistoric tsunami event or extreme storm event or neither, Abstract Volume of the Geological Society of America, 37, 75, Salt Lake City, Utah, USA, 2005.

Huntley, D. and Clague, J.: Optical dating of tsunami-laid sands, Quaternary Res., 46, 127-140, 1996.

Jankaew, K., Atwater, B. F., Sawai, Y., Choowong, M., Charoentitirat, T., Martin, M. E., and Prendergast, A.: Medieval forewarning of the 2004 Indian Ocean tsunami in Thailand, Nature, 455, 1228-1231, 2008.

Jankaew, K., Martin, M. E., Sawai, Y., and Prendergast, A.: Sand Sheets on a Beach-Ridge Plain in Thailand: Identification and Dating of Tsunami Deposits in a Far-Field Tropical Setting, in: The Tsunami Threat - Research and Technology, edited by: Mörner, N. A., 299-324, 2011.

Kayanne, H., Ikeda, Y., Echigo, T., Shishikura, M., Kamataki, T., Satake, K., Malik, J. N., Basir, S. R., Chakrabortty, K. G., and Roy, A.: Coseismic and postseismic creep in the Andaman Islands associated with the 2004 Sumatra-Andaman earthquake, Geophys. Res. Lett., 34, L01310, doi:10.1029/2006GL028200, 2007.

Kelletat, D., Scheffers, S. R., and Scheffers, A.: Field signatures of the SE-Asian mega-tsunami along the west coast of Thailand compared to Holocene paleo-tsunami from the Atlantic region, Pure Appl. Geophys., 164, 413-431, 2007.

Kulig, G.: Erstellung einer Auswertesoftware zur Altersbestimmung mittels Lumineszenzverfahren unter spezieller Berücksichtigung des Einflusses radioaktiver Ungleichgewichte in der 238-U-Zerfallsreihe, Bakkalaureusarbeit Network Computing, TU Freiberg, 2005.

Kumar, K. A. and Achyuthan, H.: A record of palaeo-tsunami in the Indian Ocean, Mar. Geod., 29, 253-263, 2006.

Lay, T., Kanamori, H., Ammon, C. J., Nettles, M., Ward, S. N., Aster, R. C., Beck, A. L., Bilek, S. L., Brudzinski, M. R., Butler, R., Deshon, H. R., Ekström, G., Satake, K., and Sipkin, S.: The great Sumatra-Andaman earthquake of 26 December 2004, Science, 308, 1127-1133, 2005.

Løvholt, F., Bungum, H., Harbitz, C. B., Glimsdal, S., Lindholm, C. D., and Pedersen, G.: Earthquake related tsunami hazard along the western coast of Thailand, Nat. Hazards Earth Syst. Sci., 6, 979-997, doi:10.5194/nhess-6-979-2006, 2006.

Madsen, A. T., Murray, A. S., Andersen, T. J., Pejrup, M., and Breuning-Madsen, H.: Optically stimulated luminescence dating of young estuarine sediments; a comparison with ${ }^{210} \mathrm{~Pb}$ and ${ }^{137}$ Cs dating, Mar. Geol., 214, 251-268, 2005.

Malik, J., Banerjee, Ch., and Shishikura, M.: Paleo-tsunami and land-level change evidence from the west coast of South Andaman, Andaman Nicobar Island, India, EGU General Assembly, Geophys. Res. Abstr., EGU2010-14667, EGU General Assembly 2010, Vienna, Austria, 2010.

Mastronuzzi, G., Brückner, H., Sansò, P., and Vött, A. (Eds.): Tsunami fingerprints in different archives - Sediments, dynamics and modelling approaches, Proceedings of the 2nd International Tsunami Field Symposium in Ostuni (Italy) and Lefkada
(Greece), Zeitschrift für Geomorphologie (Annals of Geomorphology), N. F., 54, Suppl. 3, 2010.

Meltzner, A. J, Sieh, K., Chiang, H. W., Shen, C. C., Suwargadi, B. W., Natawidjaja, D. H., Philibosian, B. E., Briggs, R. W., and Galetzka, J.: Coral evidence for earthquake recurrence and an AD 1390-1455 cluster at the south end of the 2004 Aceh-Andaman rupture, J. Geophys. Res., 115, B10402, doi:10.1029/2010JB007499, 2010.

Monecke, K., Finger, W., Klarer, D., Kongko, W., McAdoo, B. G., Moore, A. L., and Sudrajat, S. U.: A 1,000-year sediment record of tsunami recurrence in northern Sumatra, Nature, 455, 1232 1234, 2008.

Morton, R., Goff, J. R., and Nichol, S.: Hydrodynamic implications of textural trends in sand deposits of the 2004 tsunami in Sri Lanka, Sediment. Geol., 207, 56-64, 2008.

Murari, M. K., Achyuthan, H., and Singhvi, A. K.: Luminescence studies on the sediments laid down by the December 2004 tsunami event: prospects for the dating of palaeo tsunamis and for the estimation of sediment fluxes, Curr. Sci. India, 92, 367371, 2007.

Murray, A. S. and Wintle, A. G.: Luminescence dating of quartz using an improved single aliquot regenerative-dose protocol, Radiat. Meas., 32, 57-73, 2000.

Murray, A. S. and Wintle, A. G.: The single aliquot regenerative dose protocol: potential for improvements in reliability, Radiat. Meas., 37, 377-381, 2003.

Murty, T. S. and Flather, R. A.: Impact of storm surges in the Bay of Bengal, J. Coast. Res., 12, 149-161, 2004.

Murty, T. S. and Rafiq, M.: A tentative list of tsunamis of the north Indian Ocean, Nat. Hazards, 4, 81-83, 1991.

Nanayama, F., Satake, K., Furukawa, R., Shimokawa, K., Atwater, B. F., Shigeno, K., and Yamaki, S.: Unusually large earthquakes inferred from tsunami deposits along the Kuril trench, Nature, 424, 660-663, 2003.

Okal, E. A. and Synolakis, C. E.: Far-field tsunami hazard from mega-thrust earthquakes in the Indian Ocean, Geophys. J. Int., 172, 995-1015, 2008.

Ortiz, M. and Bilham, R.: Source area and rupture parameters of the 31 December $1881 \mathrm{Mw} 7.9$ Car Nicobar earthquake estimated from tsunamis recorded in the Bay of Bengal, J. Geophys. Res., 108, 2215, doi:10.1029/2002JB001941, 2003.

Paris, R., Wassmer, P., Sartohadi, J., Lavigne, F., Barthomeuf, B., Desgages, E., Grancher, D., Baumert, P., Vautier, F., Brunstein, D., and Gomez, C.: Tsunamis as geomorphic crises: lessons from the December 26, 2004 tsunami in Lhok Nga, West Banda Aceh (Sumatra, Indonesia), Geomorphology, 104, 59-72, 2009.

Pielke, R. J. and Pielke, R. S.: Hurricanes: Their nature and impacts on society, Chichester, 1997.

Pinegina, T., Bourgeois, J., Bazanova, L., Melekestsev, I., and Braitseva, O.: A millennial-scale record of Holocene tsunamis on the Kronotskiy Bay coast, Kamchatka, Russia, Quaternary Res., 59, 36-57, 2003.

Prendergast, A., Cupper, M. L., Jankaew, K., and Sawai, Y.: Indian Ocean tsunami recurrence from optical dating of tsunami sand sheets in Thailand, Mar. Geol., 295-298, 20-27, 2012.

Preusser, F., Degering, D., Fuchs, M., Hilgers, A., Kadereit, A., Klasen, N., Krbetschek, M., Richter, D., and Spencer, J.: Luminescence dating: basics, methods and applications, Quaternary Sci. J. (Eiszeitalter und Gegenwart), 57, 95-149, 2008. 
Rajendran, C. P., Rajendran, K., Machado, T., Satyamurthy, T., Aravazhi, P., and Jaiswal, M.: Evidence of ancient sea surges at the Mamallapuram coast of India and implications for previous Indian Ocean tsunami events, Curr. Sci. India, 91, 1242-1247, 2006.

Rajendran, K., Rajendran, C. P., Earnest, A., Ravi Prasad, G. V., Dutta, K., Ray, D. K., and Anu, R.: Age estimates of coastal terraces in the Andaman and Nicobar Islands and their tectonic implications, Tectonophysics, 455, 53-60, 2008.

Ranasinghage, P. N., Ortiz, J. D., Moore, A. L., Siriwardana, C., and McAdoo, B. G.: Signatures of paleo-coastal hazards in backbarrier environments of eastern and southeastern Sri Lanka, Abstract volume of the AGU Fall Meeting, San Francisco, USA, 2010.

Reimer, P. J., Baillie, M. G. L., Bard, E., Bayliss, A., Beck, J. W., Blackwell, P. G., Bronk Ramsey, C., Buck, C. E., Burr, G. S., Edwards, R. L., Friedrich, M., Grootes, P. M., Guilderson, T. P., Hajdas, I., Heaton, T. J., Hogg, A. G., Hughen, K. A., Kaiser, K. F., Kromer, B., McCormac, F.G., Manning, S. W., Reimer, R. W., Richards, D. A., Southon, J. R., Talamo, S., Turney, C. S. M., van der Plicht, J., and Weyhenmeyer, C. E.: IntCal09 and Marine09 radiocarbon age calibration curves, 0-50,000 years cal BP, Radiocarbon, 51, 1111-1150, 2009.

Sawai, Y., Jankaew, K., Martin, M. E., Prendergast, A., Choowong, M., and Charoentitirat, T.: Diatom assemblages in tsunami deposits associated with the 2004 Indian Ocean tsunami at Phra Thong Island, Thailand, Mar. Micropaleontol., 73, 70-79, 2009.

Scheffers, A., Brill, D., Kelletat, D., Brückner, H., Scheffers, S., and Fox, K.: Holocene sea levels along the Andaman Sea Coast of Thailand, The Holocene, in press, doi:10.1177/0959683612441803, 2012.

Sibuet, J.-C., Rangin, C., Le Pichon, X., Singh, S., Cattaneo, A., Graindorge, D., Klingelhoefer, F., Lin, Y. L., Malod, J., Maury, T., Schneider, J. L., Sultan, N., Umber, M., and Yamaguchi, H.: 26th December 2004 great Sumatra-Andaman earthquake: Co-seismic and post-seismic motions in northern Sumatra, Earth Planet. Sci. Lett., 263, 88-103, 2007.

Sieh, K., Natawidjaja, D. H., Meltzner, A. J., Shen, Ch., Cheng, H., Li, K., Suwargadi, B. W., Galetzka, J., Philibosian, B., and Edwards, R. L.: Earthquake supercycles inferred from the sealevel changes recorded in the corals of West Sumatra, Science, 322, 1674-1678, 2008.
Singh, O. P., Ali Khan, T. M., and Rahman, M. S.: Changes in the frequency of tropical cyclones over the North Indian Ocean, Meteorol. Atmos. Phys., 75, 11-20, 2000.

Sinsakul, S.: Evidence of Quaternary sea level changes in the coastal areas of Thailand: A review, J. Southe. Asian Earth, 7, 23-37, 1992.

Srinivasalu, S., Thangadurai, N., Switzer, A. D., Ram Mohan, V., and Ayyamperumal, T.: Erosion and sedimentation in Kalpakkam (N Tamil Nadu, India) from the 26th December 2004 tsunami, Mar. Geol., 240, 65-75, 2007.

Subarya, C., Chlieh, M., Prawirodirdjo, L., Avouac, J. P., Bock, Y., Sieh, K., Meltzner, A. J., Natawidjaja, D. H., and McCaffery, R.: Plate-boundary deformation associated with the great SumatraAndaman earthquake, Nature, 440, 46-51, 2006.

Switzer, A. D., Srinivasalu, S., Thangadurai, N., and Ram Mohan, V.: Bedding structures in Indian tsunami deposits provide clues to the dynamics of tsunami inundation, Geological Society of London, 2012.

Szczuciński, W.: The post-depositional changes of the onshore 2004 tsunami deposits on the Andaman Sea coast of Thailand, Nat. Hazards, 60, 115-133, 2012.

Szczuciński, W., Chaimanee, N., Niedzielski, P., Rachlewicz, G., Saisuttichai, D., Tepsuwan, T., Lorenc, S., and Siepak, J.: Environmental and geological impacts of the 26 December 2004 Tsunami in coastal zone of Thailand - overview of short and long-term effects, Polish J. Environ. Studies, 15, 793-810, 2006.

Tjia, H. D.: Sea-Level Changes in the tectonically stable MalayThai Peninsula, Quaternary Int., 31, 95-101, 1996.

Watkinson, I., Elders, C., and Hall, R.: The kinematic history of the Khlong Marui and Ranong Faults, southern Thailand, J. Struct. Geol., 30, 1554-1571, 2008.

Wintle, A. G. and Murray, A. S.: A review of quartz optically stimulated luminescence characteristics and their relevance in singlealiquot regeneration dating protocols, Radiat. Meas., 41, 369391, 2006. 